\title{
LEVEL II SCOUR ANALYSIS FOR BRIDGE 49 (WODSTH00990049) on TOWN HIGHWAY 99, crossing GULF BROOK, WOODSTOCK, VERMONT
}

U.S. Geological Survey Open-File Report 96-639

Prepared in cooperation with

VERMONT AGENCY OF TRANSPORTATION and

FEDERAL HIGHWAY ADMINISTRATION 


\section{LEVEL II SCOUR ANALYSIS FOR BRIDGE 49 (WODSTH00990049) on TOWN HIGHWAY 99, crossing GULF BROOK, WOODSTOCK, VERMONT \\ By SCOTT A. OLSON and ROBERT E. HAMMOND}

U.S. Geological Survey Open-File Report 96-639

Prepared in cooperation with

VERMONT AGENCY OF TRANSPORTATION

and

FEDERAL HIGHWAY ADMINISTRATION 


\title{
U.S. DEPARTMENT OF THE INTERIOR BRUCE BABBITT, Secretary
}

\author{
U.S. GEOLOGICAL SURVEY \\ Gordon P. Eaton, Director
}

For additional information write to:

District Chief

U.S. Geological Survey 361 Commerce Way

Pembroke, NH 03275-3718
Copies of this report may be purchased from:

U.S. Geological Survey

Branch of Information Services

Open-File Reports Unit

Box 25286

Denver, CO 80225-0286 


\section{CONTENTS}

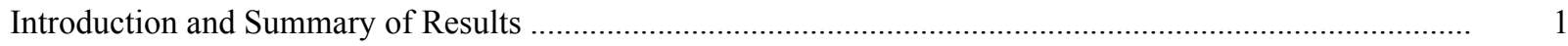

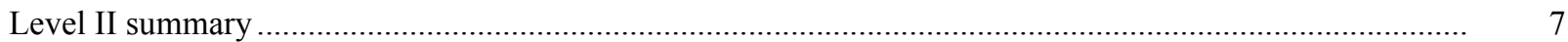

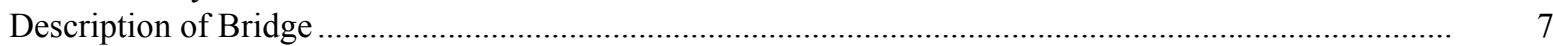

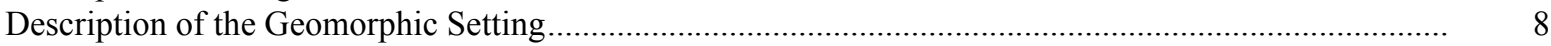

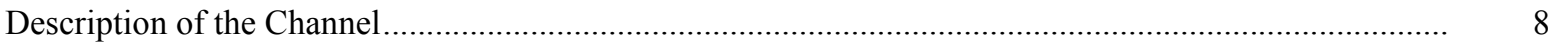

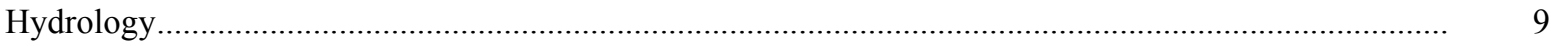

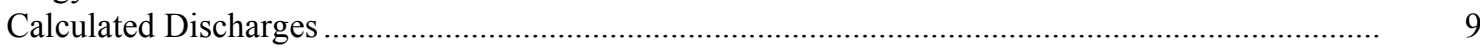

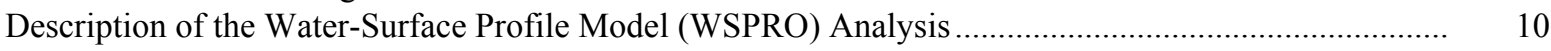

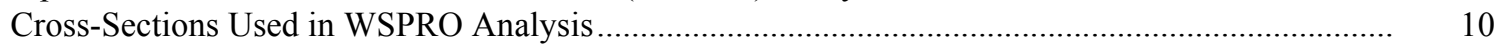

Data and Assumptions Used in WSPRO Model ...................................................................... 11

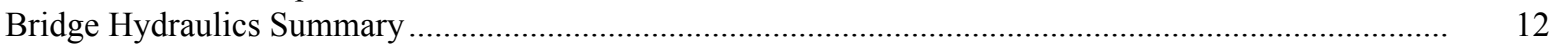

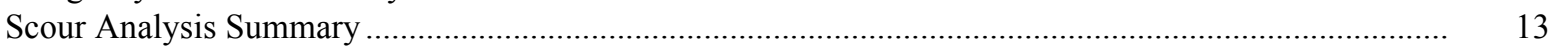

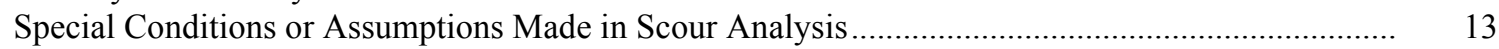

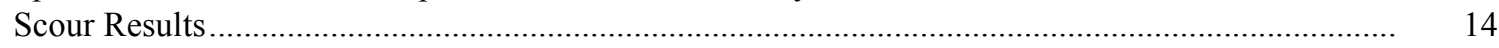

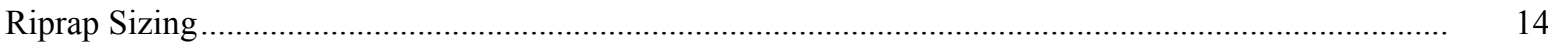

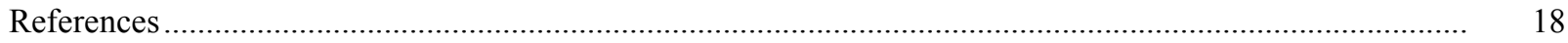

Appendixes:

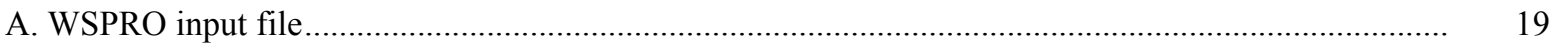

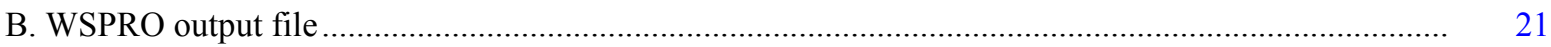

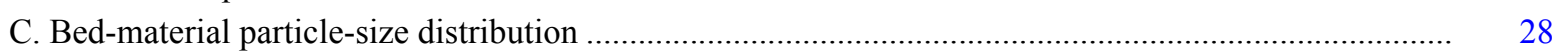

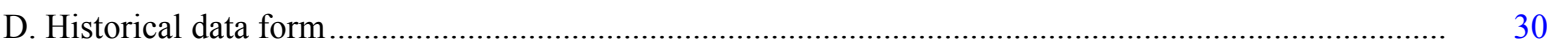

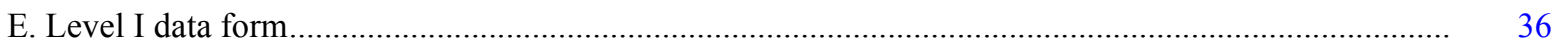

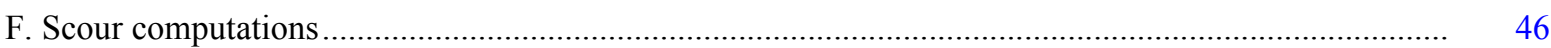

\section{FIGURES}

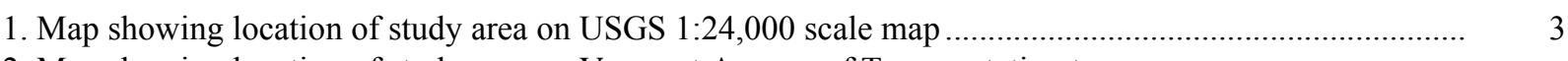

2. Map showing location of study area on Vermont Agency of Transportation town

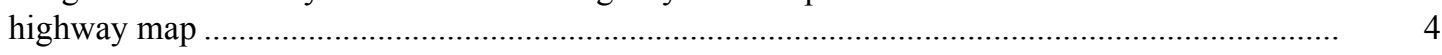

3. Structure WODSTH00990049 viewed from upstream (September 15, 1994) ......................................... 5

4. Downstream channel viewed from structure WODSTH00990049 (September 15, 1994)....................... 5

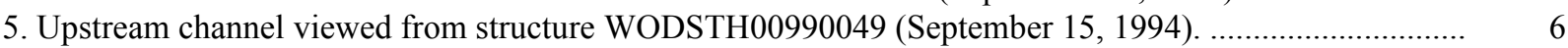

6. Structure WODSTH00990049 viewed from downstream (September 15, 1994).................................. 6

7. Water-surface profiles for the 100- and 500-year discharges at structure WODSTH00990049 on Town Highway 99, crossing Gulf Brook,

Woodstock, Vermont.

8. Scour elevations for the 100- and 500-year discharges at structure

WODSTH00990049 on Town Highway 99, crossing Gulf Brook,

Woodstock, Vermont. 3

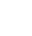

5

6




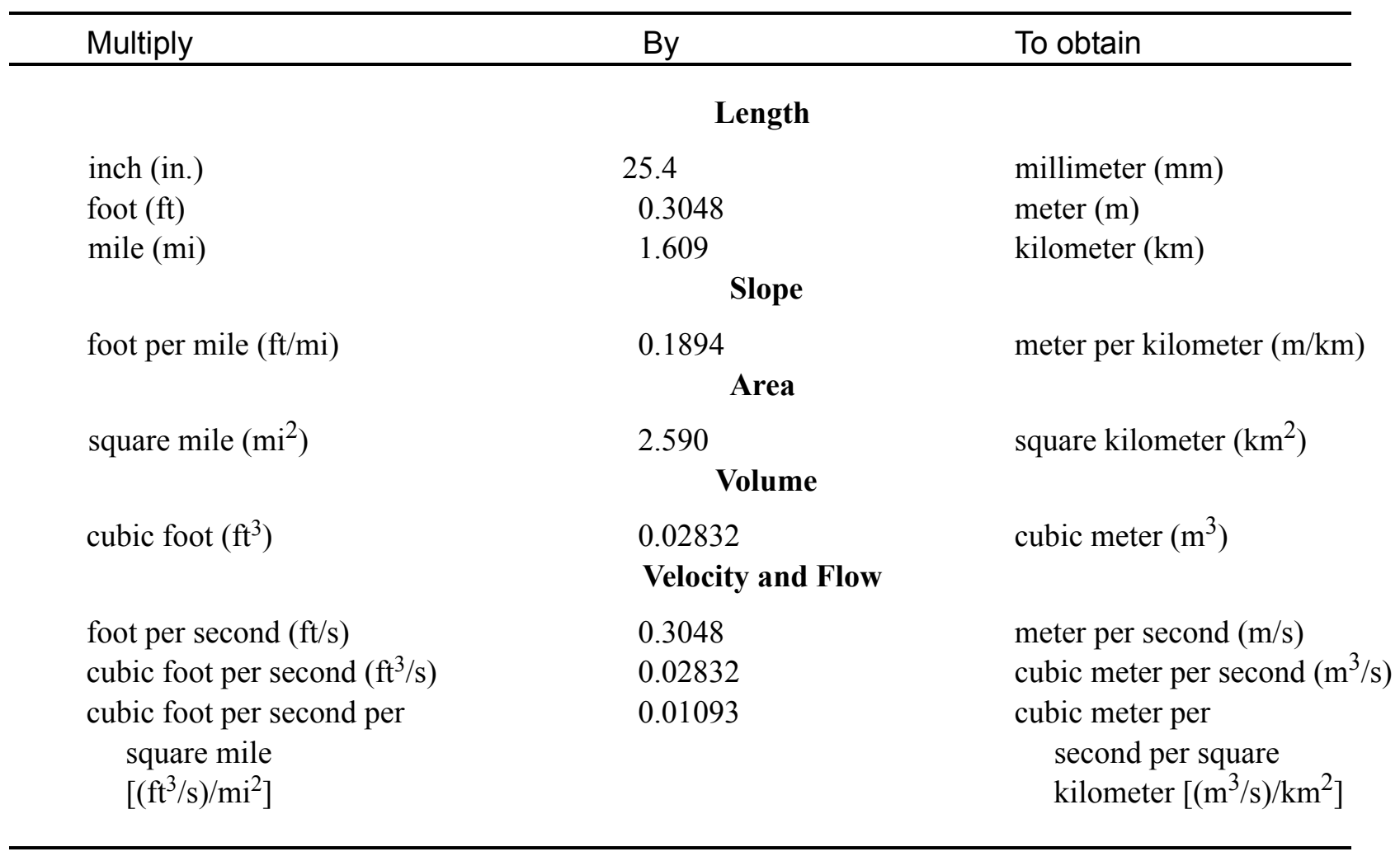

\section{OTHER ABBREVIATIONS}

$\begin{array}{lrlr}\mathrm{BF} & \text { bank full } & \text { LWW } & \text { left wingwall } \\ \mathrm{cfs} & \text { cubic feet per second } & \text { MC } & \text { main channel } \\ \mathrm{D}_{50} & \text { median diameter of bed material } & \text { RAB } & \text { right abutment } \\ \mathrm{DS} & \text { downstream } & \text { RABUT } & \text { face of right abutment } \\ \mathrm{elev} & \text { elevation } & \text { RB } & \text { right bank } \\ \mathrm{f} / \mathrm{p} & \text { flood plain } & \text { ROB } & \text { right overbank } \\ \mathrm{ft}^{2} & \text { square feet } & \text { RWW } & \text { right wingwall } \\ \mathrm{ft} / \mathrm{ft} & \text { feet per foot } & \text { TH } & \text { town highway } \\ \mathrm{JCT} & \text { junction } & \text { UB } & \text { under bridge } \\ \mathrm{LAB} & \text { left abutment } & \text { US } & \text { upstream } \\ \mathrm{LABUT} & \text { face of left abutment } & \text { USGS } & \text { United States Geological Survey } \\ \mathrm{LB} & \text { left bank } & \text { VTAOT Vermont Agency of Transportation } \\ \mathrm{LOB} & \text { left overbank } & \text { WSPRO } & \text { water-surface profile model }\end{array}$

In this report, the words "right" and "left" refer to directions that would be reported by an observer facing downstream. Sea level: In this report, "sea level" refers to the National Geodetic Vertical Datum of 1929-- a geodetic datum derived from a general adjustment of the first-order level nets of the United States and Canada, formerly called Sea Level Datum of 1929.

In the appendices, the above abbreviations may be combined. For example, USLB would represent upstream left bank. 


\title{
LEVEL II SCOUR ANALYSIS FOR BRIDGE 49 (WODSTH00990049) ON TOWN HIGHWAY 99, CROSSING GULF BROOK, WOODSTOCK, VERMONT
}

\author{
By Scott A. Olson and Robert E. Hammond
}

\section{INTRODUCTION AND SUMMARY OF RESULTS}

This report provides the results of a detailed Level II analysis of scour potential at structure WODSTH00990049 on Town Highway 99 crossing the Gulf Brook, Woodstock, Vermont (figures 1-8). A Level II study is a basic engineering analysis of the site, including a quantitative analysis of stream stability and scour (U.S. Department of Transportation, 1993). Results of a Level I scour investigation also are included in Appendix E of this report. A Level I investigation provides a qualitative geomorphic characterization of the study site. Information on the bridge, gleaned from Vermont Agency of Transportation (VTAOT) files, was compiled prior to conducting Level I and Level II analyses and is found in Appendix D.

The site is in the New England Upland section of the New England physiographic province in east-central Vermont. The $16.8-\mathrm{mi}^{2}$ drainage area is in a predominantly rural and forested basin. In the vicinity of the study site, the primary surface cover is pasture except for upstream right of the bridge which is cover by trees and brush. The immediate banks throughout the reach have scattered woody vegetation.

In the study area, the Gulf Brook has an incised, sinuous channel with a slope of approximately $0.01 \mathrm{ft} / \mathrm{ft}$, an average channel top width of $91 \mathrm{ft}$ and an average channel depth of $6 \mathrm{ft}$. The channel bed materials range from sand to cobble with a median grain size $\left(D_{50}\right)$ of $85.3 \mathrm{~mm}(0.280 \mathrm{ft})$. The geomorphic assessment at the time of the Level I site visits on September 15, 1994 and December 14, 1994, indicated that the reach was stable.

The Town Highway 99 crossing of the Gulf Brook is a 56-ft-long, one-lane bridge consisting of one 55-foot steel-beam span (Vermont Agency of Transportation, written communication, April 4, 1995). The bridge is supported by vertical, concrete abutments with a spill-through slope constructed of large quarried stone. The channel is skewed approximately 20 degrees to the opening while the opening-skew-to-roadway is 0 degrees.

Erosion at the right abutment has undermined the toe of the spill-through slope by nearly a foot. Material has been removed from under the stone spill-through slope so that 0.5 feet of horizontal penetration was possible at the time of the visits. Additional details describing conditions at the site are included in the Level II Summary and Appendices D and E. 
Scour depths and rock rip-rap sizes were computed using the general guidelines described in Hydraulic Engineering Circular 18 (Richardson and others, 1995). Total scour at a highway crossing is comprised of three components: 1) long-term streambed degradation; 2) contraction scour (due to accelerated flow caused by a reduction in flow area at a bridge) and; 3) local scour (caused by accelerated flow around piers and abutments). Total scour is the sum of the three components. Equations are available to compute depths for contraction and local scour and a summary of the results of these computations follows.

Contraction scour for all modelled flows ranged from 0.0 to $0.9 \mathrm{ft}$. The worst-case contraction scour occurred at the 500-year discharge. Abutment scour at the left abutment ranged from 3.1 to $10.3 \mathrm{ft}$. with the worst-case occurring at the 500-year discharge. Abutment scour at the right abutment ranged from 6.4 to $10.4 \mathrm{ft}$. with the worst-case occurring at the 100-year discharge.Additional information on scour depths and depths to armoring are included in the section titled "Scour Results". Scoured-streambed elevations, based on the calculated scour depths, are presented in tables 1 and 2. A cross-section of the scour computed at the bridge is presented in figure 8. Scour depths were calculated assuming an infinite depth of erosive material and a homogeneous particle-size distribution.

It is generally accepted that the Froehlich equation (abutment scour) gives "excessively conservative estimates of scour depths" (Richardson and others, 1995, p. 47). Usually, computed scour depths are evaluated in combination with other information including (but not limited to) historical performance during flood events, the geomorphic stability assessment, existing scour protection measures, and the results of the hydraulic analyses. Therefore, scour depths adopted by VTAOT may differ from the computed values documented herein. 


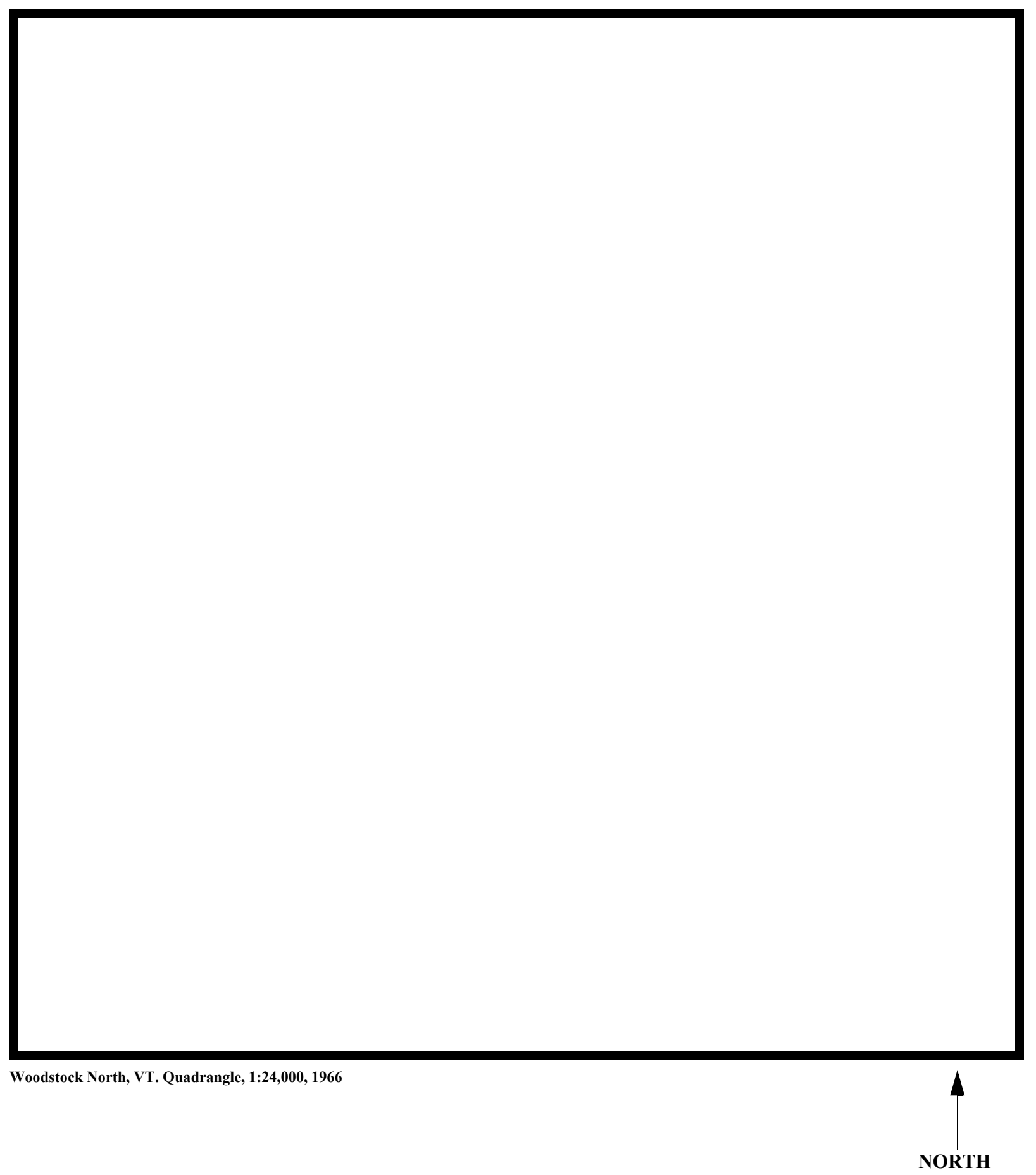

Figure 1. Location of study area on USGS 1:24,000 scale map. 
Figure 2. Location of study area on Vermont Agency of Transportation town highway map. 

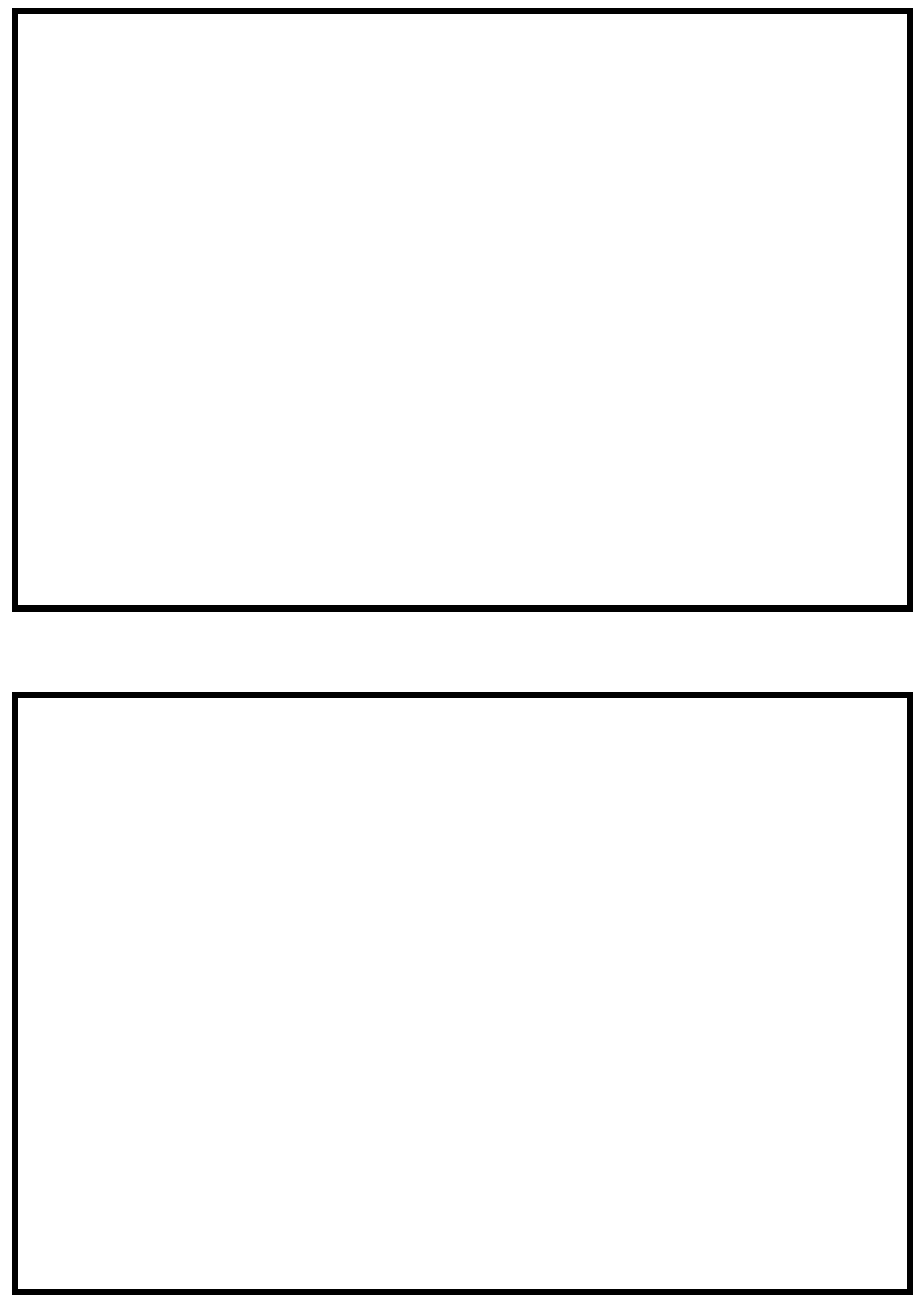

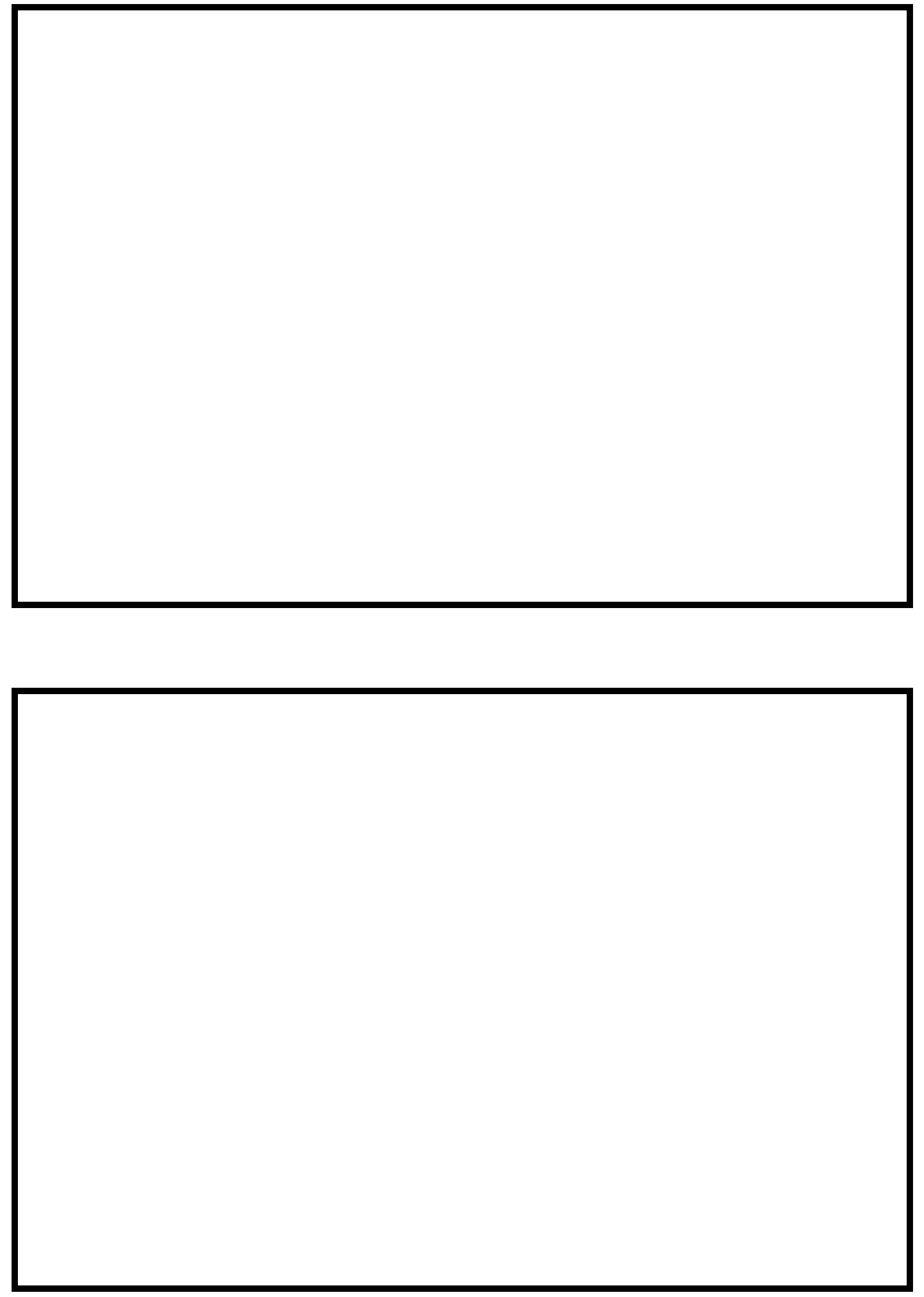


\section{LEVEL II SUMMARY}

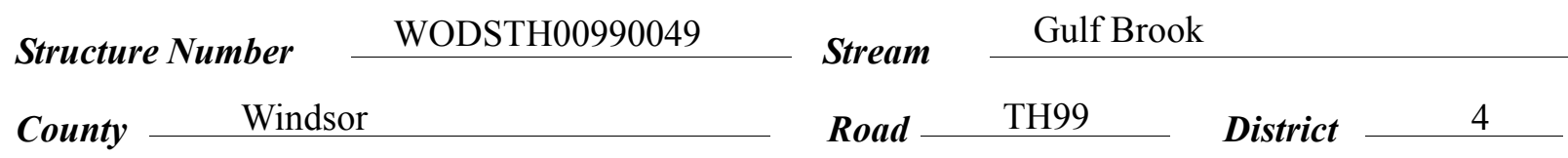

\section{Description of Bridge}

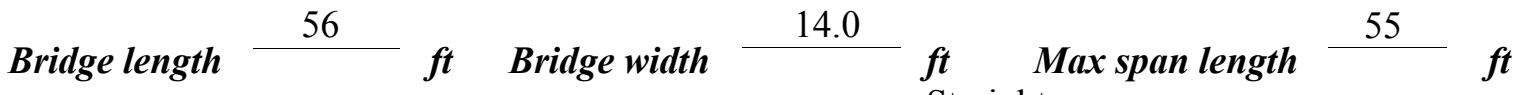
Alignment of bridge to road (on curve or straight)

Abutment type Spill-through

Stone fill on abutment?

$$
\text { Yes }
$$

\section{Embankment type} Straight

Dato af insnortinn $3 \mathrm{ft}$ by $3 \mathrm{ft}$ by $2 \mathrm{ft}$ quarried stone block are used for the face of the abutment spill-through slope.

Concrete abutment with stone spill-through slopes

along the abutment face. Toe of spill-through slope on right abutment is experiencing undermining.

$$
\text { Yes }
$$

Is bridge skewed to flood flow according to Y r survey?

Mild bend in the reach. Landowner report that the channel was moved and straightened upstream of the bridge after the 1973 flood.

\begin{tabular}{|c|c|c|c|}
\hline & $\begin{array}{l}\text { Dato of in snortion } \\
9 / 15 / 94 \text { and } 12 / 14 / 94\end{array}$ & $\begin{array}{l}\text { Percent of alommal } \\
\text { blocked inorizontatly }\end{array}$ & $\begin{array}{l}\text { Percent of } 0 \\
\text { blocked verticatty }\end{array}$ \\
\hline Level I & $9 / 15 / 94$ & 0 & 0 \\
\hline el II & Low. & & \\
\hline
\end{tabular}

Debris accumulation on bridge at time of Level I or Level II site visit:

\section{Potential for debris}

The right abutment protrudes out into the channel about ten feet. 


\section{Description of the Geomorphic Setting}

General topography The channel is located within a wide, irregular flood plain with steep valley walls on both sides.

Geomorphic conditions at bridge site: downstream (DS), upstream (US)

Date of inspection $\quad 9 / 15 / 94$ and 12/14/94

DS left: $\quad$ Flood plain to moderately sloped valley wall.

DS right: $\quad$ Flood plain to moderately sloped valley wall.

US left: $\quad$ Flood plain to moderately sloped valley wall.

US right: $\quad$ Flood plain to moderately sloped valley wall.

\section{Description of the Channel}

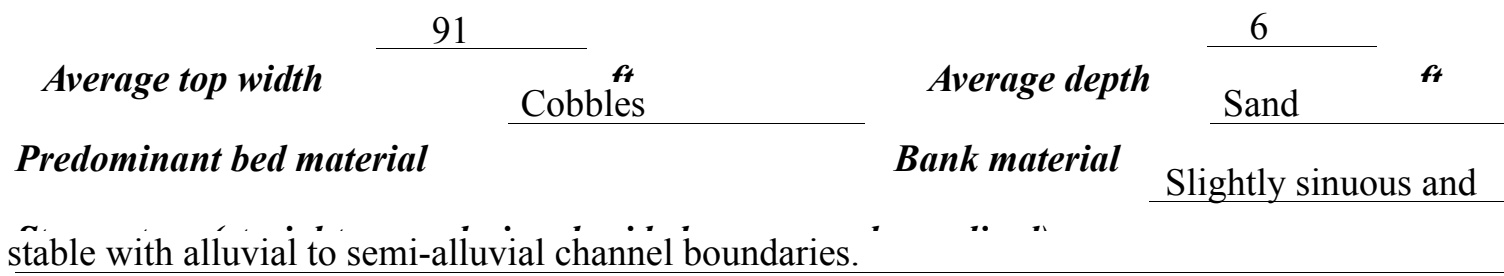

$11 / 08 / 94$

Vegetative co Grass with a few trees on immediate bank. V̈T Route 12 parallels bank

DS left: $\quad$ Grass with a few trees on immediate bank.

DS right: $\quad$ Grass with a few trees on immediate bank. VT Route 12 parallels bank

US left: $\quad$ Trees and brush with grass on far overbank.

US right: $\quad \underline{\mathrm{Y}}$

Do banks appear stable? -

date of observatton.

None. September 15,

1994 and December 14, 1994.

Describe any obstructions in channel and date of observation. 


\title{
Hydrology
}

Drainage area $\frac{16.8}{m^{2}}{ }^{2}$

Percentage of drainage area in physiographic provinces: (approximate)

Physiographic province/section New England Upland
Percent of drainage area 100

\begin{abstract}
Is drainage area considered rural or urban?
Rural urbanization:

Describe any significant
\end{abstract}

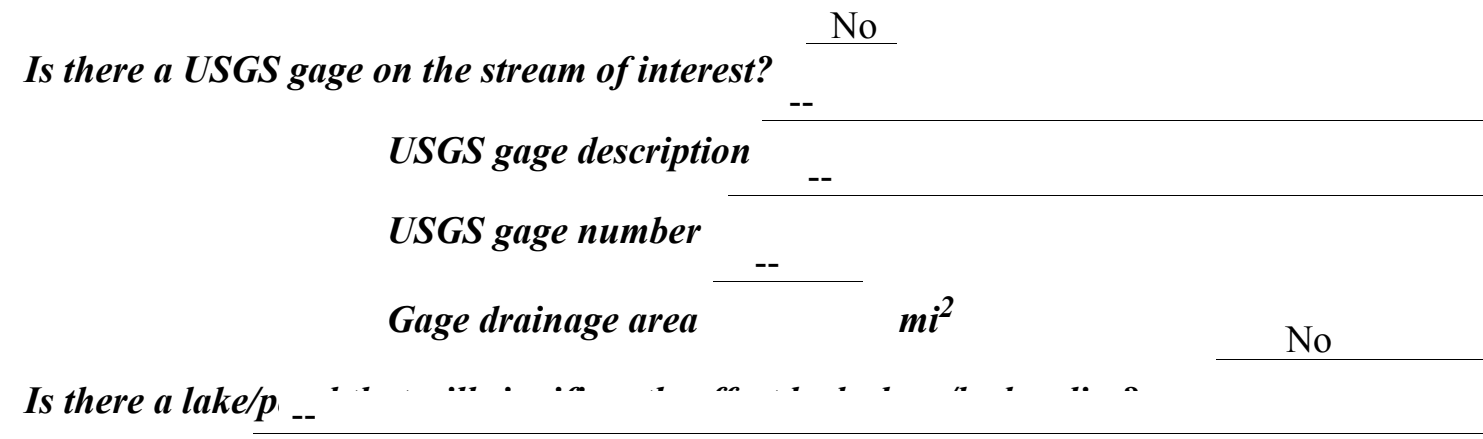

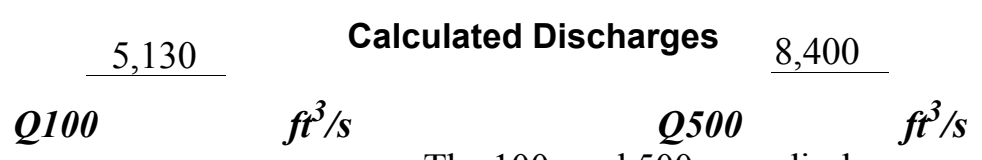

The 100- and 500-year discharges were interpolated

between flood frequency estimates at two locations on Gulf Brook in the Flood Insurance Study for the Town of Woodstock (Federal Emergency Management Agency, 1979). The discharges were within a ranged defined by several empirical methods for estimating flood discharges (Benson, 1962; Johnson and Tasker, 1974; FHWA, 1983; Potter, 1957a\&b; Talbot, 1887) 


\section{Description of the Water-Surface Profile Model (WSPRO) Analysis}

Datum for WSPRO analysis (USGS survey, sea level, VTAOT plans)

USGS survey

Datum tie between USGS survey and VTAOT plans

Subtract 4280.0 from USGS

survey to obtain VTAOT plans' datum $(+/-0.2 \mathrm{ft})$.

Description of reference marks used to determine USGS datum. $\quad$ RM1 is a chiseled

square on top of the downstream end of the left abutment (elev. $5001.00 \mathrm{ft}$, arbitrary survey

datum). RM2 is a chiseled square on top of the upstream end of the right abutment (elev.

$5000.33 \mathrm{ft}$, arbitrary survey datum).

\section{Cross-Sections Used in WSPRO Analysis}

\begin{tabular}{ccll}
\hline${ }^{1}$ Cross-section & $\begin{array}{c}\text { Section } \\
\text { Reference } \\
\text { Distance } \\
\text { (SRD) in feet }\end{array}$ & $\begin{array}{c}{ }^{2} \text { Cross-section } \\
\text { development }\end{array}$ & \multicolumn{1}{c}{ Comments } \\
\hline EXIT1 & -117 & 1 & Exit section \\
FULLV & 0 & 2 & $\begin{array}{l}\text { Downstream Full-valley } \\
\text { section (Templated from } \\
\text { EXIT1) }\end{array}$ \\
BRDGE & 0 & 1 & $\begin{array}{l}\text { Bridge section } \\
\text { Road Grade section }\end{array}$ \\
RDWY & 7 & 1 & $\begin{array}{l}\text { Modelled Approach sec- } \\
\text { tion (Templated from } \\
\text { APTEM) }\end{array}$ \\
APTEM & 67 & 2 & $\begin{array}{l}\text { Approach section as sur- } \\
\text { veyed (Used as a tem- } \\
\text { plate) }\end{array}$ \\
\hline
\end{tabular}

${ }^{1}$ For location of cross-sections see plan-view sketch included with Level I field form, Appendix E.

For more detail on how cross-sections were developed see WSPRO input file. 


\section{Data and Assumptions Used in WSPRO Model}

Hydraulic analyses of the reach were done by use of the Federal Highway Administration's WSPRO step-backwater computer program (Shearman and others, 1986, and Shearman, 1990). The analyses reported herein reflect conditions existing at the site at the time of the study. Furthermore, in the development of the model it was necessary to assume no accumulation of debris or ice at the site. Results of the hydraulic model are presented in the Bridge Hydraulic Summary, Appendix B, and figure 7.

Channel roughness factors (Manning's " $n$ ") used in the hydraulic model were estimated using field inspections at each cross section following the general guidelines described by Arcement and Schneider (1989). Final adjustments to the values were made during the modelling of the reach. Channel " $n$ " values for the reach ranged from 0.053 to 0.055 , and overbank " $\mathrm{n}$ " values ranged from 0.036 to 0.110 .

Normal depth at the exit section (EXIT1) was assumed as the starting water surface. This depth was computed by use of the slope-conveyance method outlined in the user's manual for WSPRO (Shearman, 1990). The slope used was $0.0104 \mathrm{ft} / \mathrm{ft}$ which was determined from the 100-year water surface profile downstream of the bridge in the Flood Insurance Study for the Town of Woodstock (Federal Emergency Management Agency, 1979).

The surveyed approach section (APTEM) was moved along the approach channel slope $(0.016 \mathrm{ft} / \mathrm{ft})$ to establish the modelled approach section (APPRO), one bridge length upstream of the upstream face as recommended by Shearman and others (1986). This approach also provides a consistent method for determining scour variables. 


\section{Bridge Hydraulics Summary}

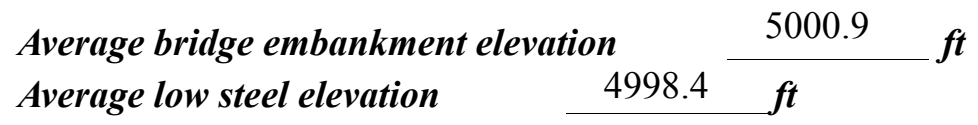

$$
\text { 100-year discharge } \quad 5,130 \quad \mathrm{ft}^{3} / \mathrm{s}
$$

Water-surface elevation in bridge opening $\quad 4998.4 \mathrm{ft}$

Road overtopping? ___ Y Discharge over road _ 2,610, s

\begin{tabular}{llll} 
Area of flow in bridge opening & $271 \quad \mathrm{ft}^{2}$ \\
\cline { 2 - 3 } Average velocity in bridge opening & 9.5 & $\mathrm{ft} / \mathrm{s}$
\end{tabular}

$\begin{array}{lll}\text { Maximum WSPRO tube velocity at bridge } & 12.3 \mathrm{ft} / \mathrm{s}\end{array}$

Water-surface elevation at Approach section with bridge 5001.9

Water-surface elevation at Approach section without bridge $\quad \overline{5000.1}$

Amount of backwater caused by bridge

1.8 it

500-year discharge $\quad 8,400 \quad \mathrm{ft}^{3} / \mathrm{s}$

Water-surface elevation in bridge opening $\quad 4998.7 \mathrm{ft}$

Road overtopping? ___ Y Discharge over road _ $\quad 5,500^{-}$

Area of flow in bridge opening $\quad 275 \quad \mathrm{ft}^{2}$

Average velocity in bridge opening $11.1 \mathrm{ft} / \mathrm{s}$

Maximum WSPRO tube velocity at bridge 13.6 's

Water-surface elevation at Approach section with bridge $\quad 5003.0$

Water-surface elevation at Approach section without bridge $\quad 5001.5$

Amount of backwater caused by bridge 1.5 .

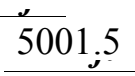

Incipient overtopping discharge $\quad 1,540 \mathrm{ft}^{3} / \mathrm{s}$

Water-surface elevation in bridge opening 4996.6 t

Area of flow in bridge opening

Average velocity in bridge opening

$180 \quad \mathrm{ft}^{2}$

Maximum WSPRO tube velocity at bridge

$8.6 \mathrm{ft} / \mathrm{s}$

$\mathrm{ft}^{\mathrm{ft} / \mathrm{s}} \mathrm{ft} / \mathrm{s}$

Water-surface elevation at Approach section with bridge

Water-surface elevation at Approach section without bridge

4998.3

Amount of backwater caused by bridge

0.9 it 


\section{Scour Analysis Summary}

\section{Special Conditions or Assumptions Made in Scour Analysis}

Scour depths were computed using the general guidelines described in Hydraulic Engineering Circular 18 (Richardson and others, 1995). Scour depths were calculated assuming an infinite depth of erosive material and a homogeneous particle-size distribution. The results of the scour analysis are presented in tables 1 and 2 and a graph of the scour depths is presented in figure 8 .

Contraction scour for the 100- and 500-year event was computed by use of the Chang pressure-flow scour equation (Richardson and others, 1995, p. 145-146). For the 100- and 500 -year discharges, there was orifice flow at the bridge. Contraction scour at bridges with orifice flow is best estimated by use of the Chang pressure-flow scour equation (oral communication, J. Sterling Jones, October 4, 1996). The results of Laursen's clear-water contraction scour equation (Richardson and others, 1995, p. 32, equation 20) for these discharges were also computed and can be found in appendix F. Contraction scour for the incipient roadway-overtopping discharges was computed by use of Laursen's clear-water contraction scour equation (Richardson and others, 1995, p. 32, equation 20).

Abutment scour was computed by use of the Froehlich equation (Richardson and others, 1995, p. 48, equation 28). Variables for the Froehlich equation include the Froude number of the flow approaching the embankments, the length of the embankment blocking flow, and the depth of flow approaching the embankment less any roadway overtopping.

Because the influence of scour processes on the spill-through embankment material is uncertain, the scour depth at the vertical concrete abutment walls is unknown. Therefore, the variables for the abutment scour equations applied were computed including the width of the spill-through embankments. The total scour depths were applied for the entire spillthrough embankment below the elevation at the toe of each embankment, as shown in figure 8. 


\section{Scour Results}

100-yr discharge 500-yr discharge

overtopping

Contraction scour:

(Scour depths in feet)

Main channel

Live-bed scour

Clear-water scour

Depth to armoring

Left overbank

Right overbank

Local scour:

Abutment scour

Left abutment

8.2

10.3

3.1

10.4

$10.3-$

$6.4-$

Right abutment

Pier scour

Pier 1

Pier 2

Pier 3

Abutments:

Left abutment

Right abutment

Piers:

Pier 1

Pier 2

\section{Riprap Sizing}

Incipient overtopping 100-yrdischarge 500-yrdischarge discharge (D $D_{50}$ in feet)

5

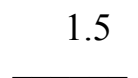

$--$
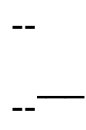

1.8

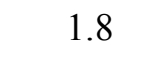

--
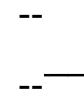

1.2

1.2 


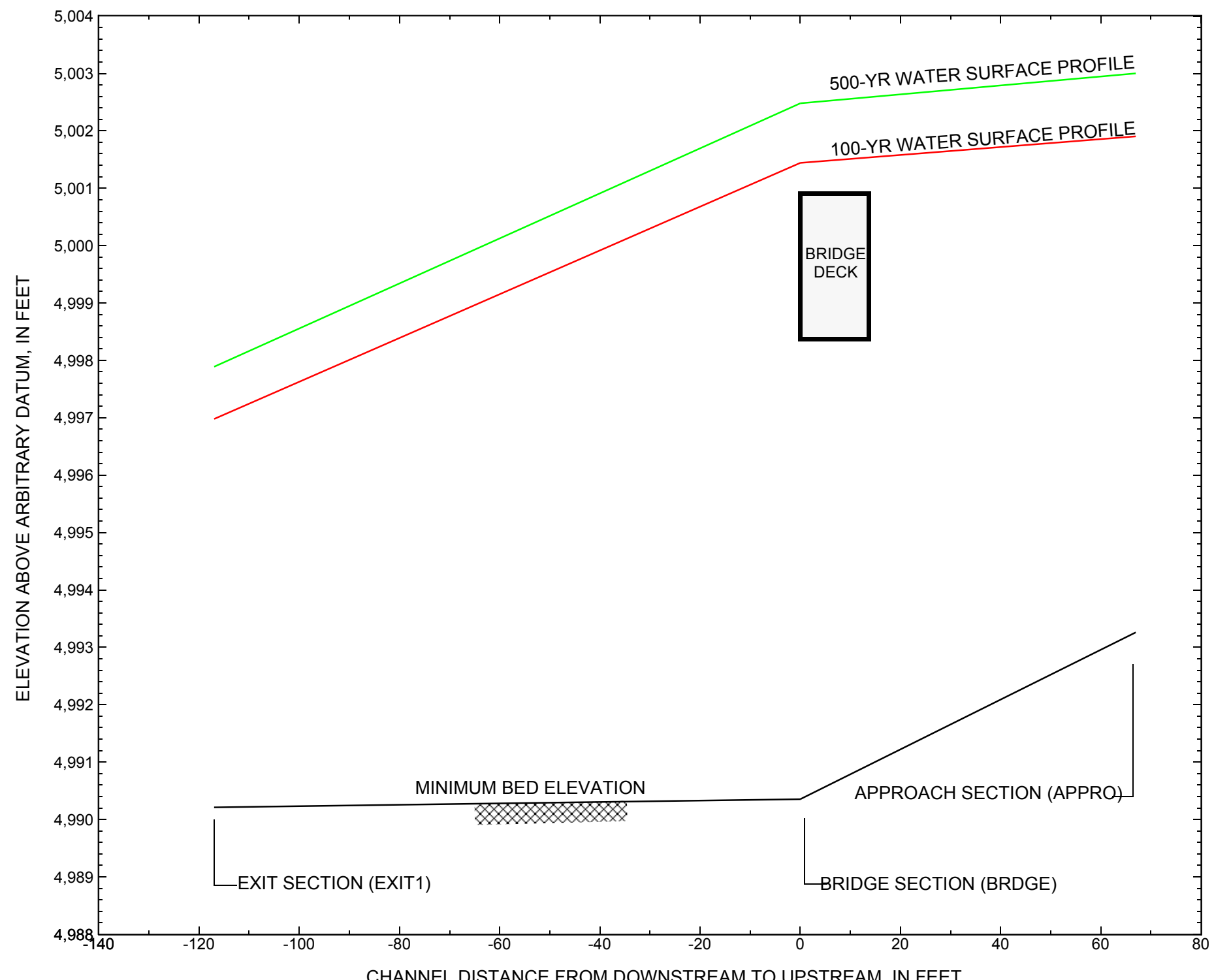

Figure 7. Water-surface profiles for the 100- and 500-yr discharges at structure WODSTH00990049 on Town Highway 99, crossing Gulf Brook, Woodstock, Vermont. 


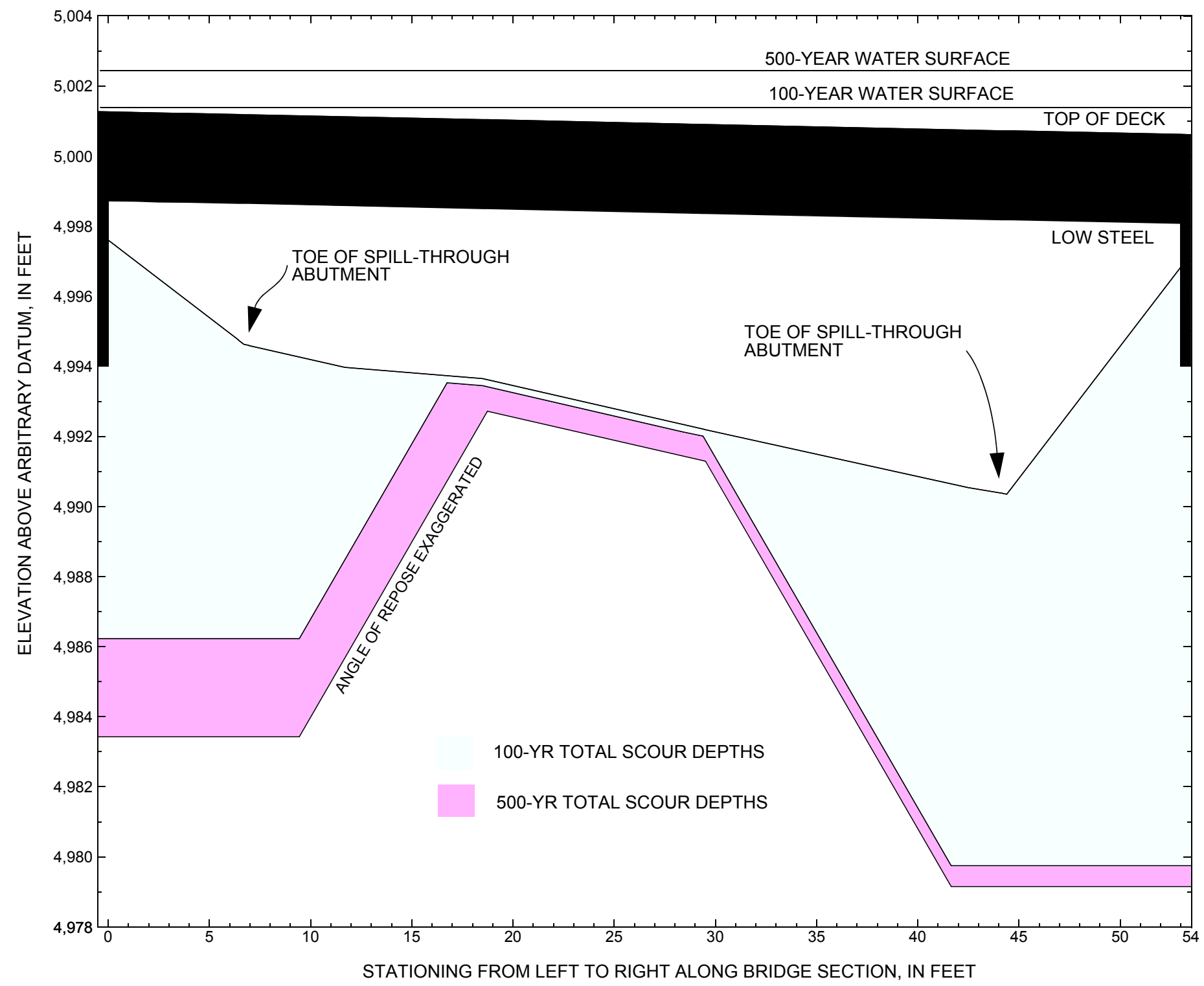

Figure 8. Scour elevations for the 100-yr and 500-yr discharges at structure WODSTH00990049 on Town Highway 99, crossing Gulf Brook, Woodstock, Vermont. 
Table 1. Remaining footing/pile depth at abutments for the 100-year discharge at structure WODSTH00990049 on Town Highway 99 , crossing Gulf Brook, Woodstock, Vermont.

[VTAOT, Vermont Agency of Transportation; --,no data]

\begin{tabular}{|c|c|c|c|c|c|c|c|c|c|c|c|}
\hline Description & Station $^{1}$ & $\begin{array}{c}\text { VTAOT } \\
\text { bridge seat } \\
\text { elevation } \\
\text { (feet) }\end{array}$ & $\begin{array}{l}\text { Surveyed } \\
\text { minimum } \\
\text { low-chord } \\
\text { elevation }{ }^{2} \\
\text { (feet) }\end{array}$ & $\begin{array}{l}\text { Bottom of } \\
\text { footing } \\
\text { elevation } \\
\text { (feet) }\end{array}$ & $\begin{array}{c}\text { Channel } \\
\text { elevation at } \\
\text { abutment/ } \\
\text { pier }^{2} \\
\text { (feet) }\end{array}$ & $\begin{array}{l}\text { Contraction } \\
\text { scour depth } \\
\text { (feet) }\end{array}$ & $\begin{array}{l}\text { Abutment } \\
\text { scour } \\
\text { depth } \\
\text { (feet) }\end{array}$ & $\begin{array}{l}\text { Pier } \\
\text { scour } \\
\text { depth } \\
\text { (feet) }\end{array}$ & $\begin{array}{l}\text { Depth of } \\
\text { total scour } \\
\text { (feet) }\end{array}$ & $\begin{array}{c}\text { Elevation of } \\
\text { scour }^{2} \\
\text { (feet) }\end{array}$ & $\begin{array}{c}\text { Remaining } \\
\text { footing/pile } \\
\text { depth } \\
\text { (feet) }\end{array}$ \\
\hline \multicolumn{12}{|c|}{100 -yr. discharge is 5,130 cubic-feet per second } \\
\hline Left abutment & 0.0 & 718.6 & 4998.7 & 4994 & -- & -- & -- & -- & -- & -- & -- \\
\hline Left abutmnet toe & 6.7 & -- & -- & -- & 4994.6 & 0.2 & 8.2 & -- & 8.4 & 4986.2 & -8 \\
\hline Right abutment toe & 44.4 & -- & -- & -- & 4990.4 & 0.2 & 10.4 & -- & 10.6 & 4979.8 & -14 \\
\hline Right abutment & 53.0 & 718.1 & 4998.1 & 4994 & -- & -- & -- & -- & -- & -- & -- \\
\hline
\end{tabular}

1.Measured along the face of the most constricting side of the bridge.

2.Arbitrary datum for this study.

Table 2. Remaining footing/pile depth at abutments for the 500-year discharge at structure WODSTH00990049 on Town Highway 99 , crossing Gulf Brook, Woodstock, Vermont.

[VTAOT, Vermont Agency of Transportation; --, no data]

\begin{tabular}{|c|c|c|c|c|c|c|c|c|c|c|c|}
\hline Description & Station $^{1}$ & $\begin{array}{c}\text { VTAOT } \\
\text { bridge seat } \\
\text { elevation } \\
\text { (feet) }\end{array}$ & $\begin{array}{c}\text { Surveyed } \\
\text { minimum } \\
\text { low-chord } \\
\text { elevation }{ }^{2} \\
\text { (feet) }\end{array}$ & $\begin{array}{l}\text { Bottom of } \\
\text { footing } \\
\text { elevation } \\
\text { (feet) }\end{array}$ & $\begin{array}{c}\text { Channel } \\
\text { elevation at } \\
\text { abutment/ } \\
\text { pier }^{2} \\
\text { (feet) }\end{array}$ & $\begin{array}{l}\text { Contraction } \\
\text { scour depth } \\
\text { (feet) }\end{array}$ & $\begin{array}{l}\text { Abutment } \\
\text { scour } \\
\text { depth } \\
\text { (feet) }\end{array}$ & $\begin{array}{l}\text { Pier } \\
\text { scour } \\
\text { depth } \\
\text { (feet) }\end{array}$ & $\begin{array}{l}\text { Depth of } \\
\text { total scour } \\
\text { (feet) }\end{array}$ & $\begin{array}{c}\text { Elevation of } \\
\text { scour }^{2} \\
\text { (feet) }\end{array}$ & $\begin{array}{c}\text { Remaining } \\
\text { footing/pile } \\
\text { depth } \\
\text { (feet) }\end{array}$ \\
\hline \multicolumn{12}{|c|}{500 -yr. discharge is 8,400 cubic-feet per second } \\
\hline Left abutment & 0.0 & 718.6 & 4998.7 & 4994 & -- & -- & -- & -- & -- & -- & -- \\
\hline Left abutment toe & 6.7 & -- & -- & -- & 4994.6 & 0.9 & 10.3 & -- & 11.2 & 4983.4 & -11 \\
\hline Right abutment toe & 44.4 & -- & -- & -- & 4990.4 & 0.9 & 10.3 & -- & 11.2 & 4979.2 & -15 \\
\hline Right abutment & 53.0 & 718.1 & 4998.1 & 4994 & -- & -- & -- & -- & -- & -- & -- \\
\hline
\end{tabular}

1.Measured along the face of the most constricting side of the bridge.

2.Arbitrary datum for this study. 


\section{SELECTED REFERENCES}

Arcement, G.J., Jr., and Schneider, V.R., 1989, Guide for selecting Manning's roughness coefficients for natural channels and flood plains: U.S. Geological Survey Water-Supply Paper 2339, 38 p.

Barnes, H.H., Jr., 1967, Roughness characteristics of natural channels: U.S. Geological Survey Water-Supply Paper 1849,213 p.

Benson, M. A., 1962, Factors Influencing the Occurrence of Floods in a Humid Region of Diverse Terrain: U.S. Geological Survey WaterSupply Paper 1580-B, 64 p.

Brown, S.A. and Clyde, E.S., 1989, Design of riprap revetment: Federal Highway Administration Hydraulic Engineering Circular No. 11, Publication FHWA-IP-89-016, 156 p.

Federal Highway Administration, 1983, Runoff estimates for small watersheds and development of sound design: Federal Highway Administration Report FHWA-RD-77-158

Federal Emergency Management Agency, 1979, Flood Insurance Study, Town of Woodstock, Windsor County, Vermont: Washington, D.C., September 1979.

Froehlich, D.C., 1989, Local scour at bridge abutments in Ports, M.A., ed., Hydraulic Engineering--Proceedings of the 1989 National Conference on Hydraulic Engineering: New York, American Society of Civil Engineers, p. 13-18.

Hayes, D.C.,1993, Site selection and collection of bridge-scour data in Delaware, Maryland, and Virginia: U.S. Geological Survey WaterResources Investigation Report 93-4017, 23 p.

Johnson, C.G. and Tasker, G.D.,1974, Progress report on flood magnitude and frequency of Vermont streams: U.S. Geological Survey OpenFile Report 74-130, 37 p.

Lagasse, P.F., Schall, J.D., Johnson, F., Richardson, E.V., Chang, F., 1995, Stream Stability at Highway Structures: Federal Highway Administration Hydraulic Engineering Circular No. 20, Publication FHWA-IP-90-014, 144 p.

Laursen, E.M., 1960, Scour at bridge crossings: Journal of the Hydraulics Division, American Society of Civil Engineers, v. 86, no. HY2, p. 39-53.

Potter, W. D., 1957a, Peak rates of runoff in the Adirondack, White Mountains, and Maine woods area, Bureau of Public Roads

Potter, W. D., 1957b, Peak rates of runoff in the New England Hill and Lowland area, Bureau of Public Roads

Richardson, E.V. and Davis, S.R., 1995, Evaluating scour at bridges: Federal Highway Administration Hydraulic Engineering Circular No. 18, Publication FHWA-IP-90-017, 204 p.

Richardson, E.V., Simons, D.B., and Julien, P.Y., 1990, Highways in the river environment: Federal Highway Administration Publication FHWA-HI-90-016.

Ritter, D.F., 1984, Process Geomorphology: W.C. Brown Co., Debuque, Iowa, 603 p.

Shearman, J.O., 1990, User's manual for WSPRO--a computer model for water surface profile computations: Federal Highway Administration Publication FHWA-IP-89-027, 187 p.

Shearman, J.O., Kirby, W.H., Schneider, V.R., and Flippo, H.N., 1986, Bridge waterways analysis model; research report: Federal Highway Administration Publication FHWA-RD-86-108, 112 p.

Talbot, A.N., 1887, The determination of water-way for bridges and culverts.

U.S. Department of Transportation, 1993, Stream stability and scour at highway bridges, Participant Workbook: Federal Highway Administration Publication FHWA HI-91-011.

U.S. Geological Survey, 1966, Woodstock North, Vermont 7.5 Minute Series quadrangle map: U.S. Geological Survey Topographic Maps, Scale 1:24,000. 


\section{APPENDIX A: \\ WSPRO INPUT FILE}




\section{WSPRO INPUT FILE}

GR

GR

GR

$\mathrm{N}$

SA

XS FULLV $0 * * * 0.0104$

BR

GR

GR

GR

$\mathrm{N}$

CD

*

$\mathrm{XR}$

GR

GR

GR

$\mathrm{XT}$

GR

GR

GR

GR

GR

AS

GT

$\mathrm{N}$

SA

\section{*}

HP 1 BRDGE

HP 2 BRDGE

HP 2 RDWY

HP 1 APPRO

HP 2 APPRO

*

HP 1 BRDGE

HP 2 BRDGE

HP 2 RDWY

HP 1 APPRO

HP 2 APPRO

*

HP 1 BRDGE

HP 2 BRDGE

$5130 \quad 8400 \quad 1540$
$-557.5,5010.35$

$-61.4,5003.02$

$11.3,4996.39$

$35.4,4993.71$

$101.1,4998.14$

$$
-0.45
$$

0.038

0.055
U.S. Geological Survey WSPRO Input File wods049.wsp Hydraulic analysis for structure WODSTH00990049 Date: 10-JUN-96 HYDRAULIC ANALYSIS OF WODS049 OVER GULF BROOK SAO

$62930 \quad 552553551516 \quad 17 \quad 13 \quad 3 * \begin{array}{llllllllll}15 & 14 & 23 & 21 & 11 & 12 & 4 & 7 & 3\end{array}$

$0.0104 \quad 0.0104 \quad 0.0104$
043.8

$0.085 \quad 0.036$

80.9

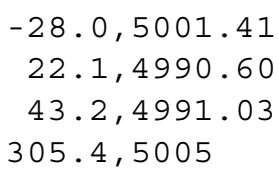

$0.0,4997.60$

$28.4,4992.33$

$53.0,4996.83$

$44.4,4990.35$

0.053

314.315000 .9

$$
\begin{array}{r}
6.7,4994.63 \\
36.5,4991.32 \\
53.0,4998.07
\end{array}
$$

$-38.9,5002.20$

$-14.8,5001.00$

$243.8,4999.01$

$-90.6,5004.73$

$56.4,5000.54$

$292.5,5005$
$0.0,5001.34$

$292.5,4998.16$

$-387.3,5005.64$
$-47.7,5000.97$
$17.3,4994.58$
$46.9,4993.78$
$111.4,5001.22$

$-259.7,5007.73$

$0.0,4999.31$

$18.5,4994.15$

$48.4,4994.51$

$294.8,4996.56$
$0.0,5000.13$

$28.2,4990.23$

$43.8,4991.42$
$11.7,4993.97$

$42.5,4990.54$

$0.0,4998.73$
67

0.110

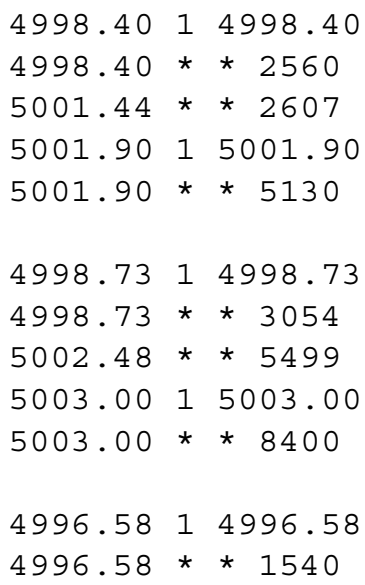




\section{APPENDIX B: \\ WSPRO OUTPUT FILE}




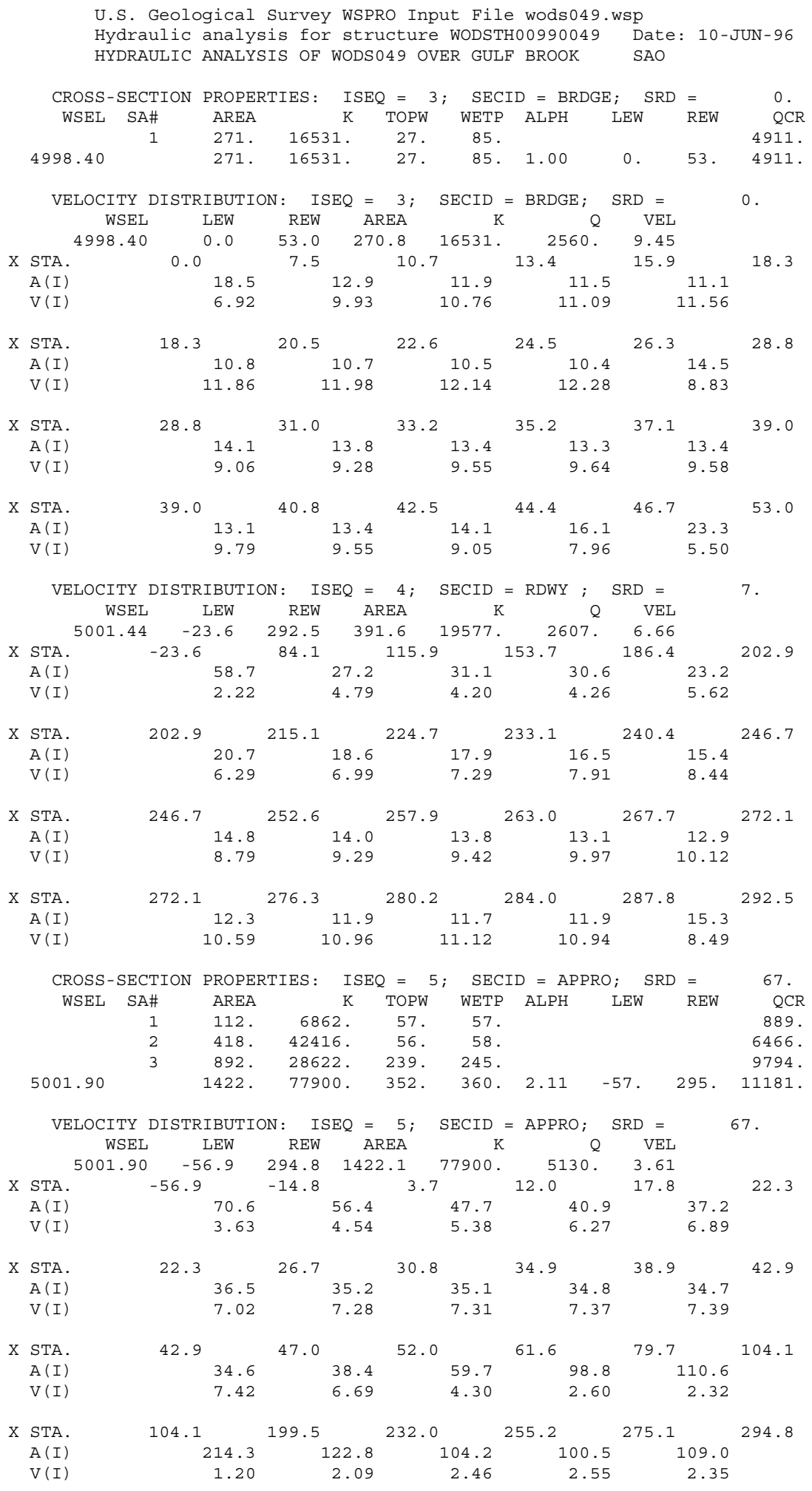


WSPRO OUTPUT FILE (continued)

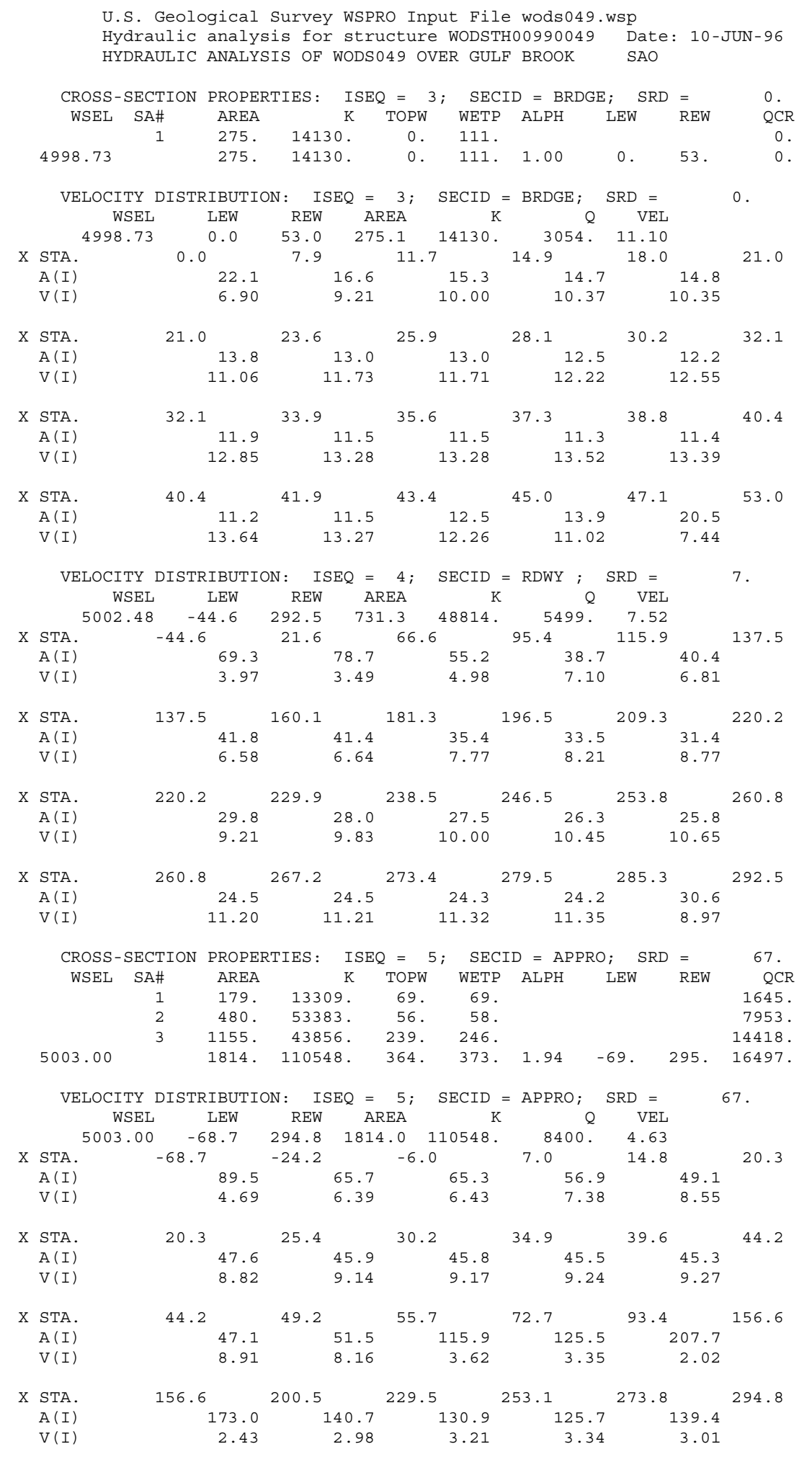


WSPRO OUTPUT FILE (continued)

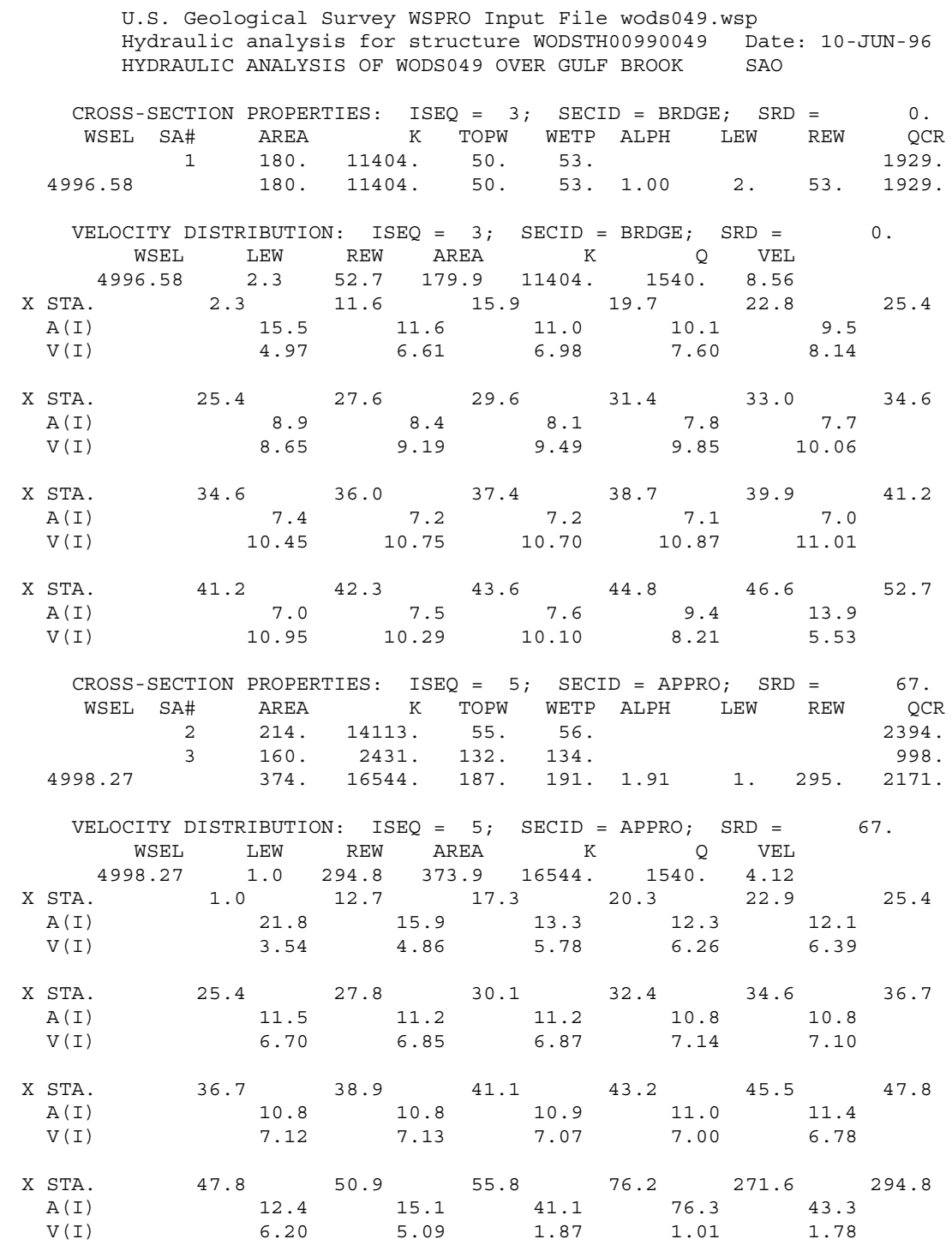


WSPRO OUTPUT FILE (continued)

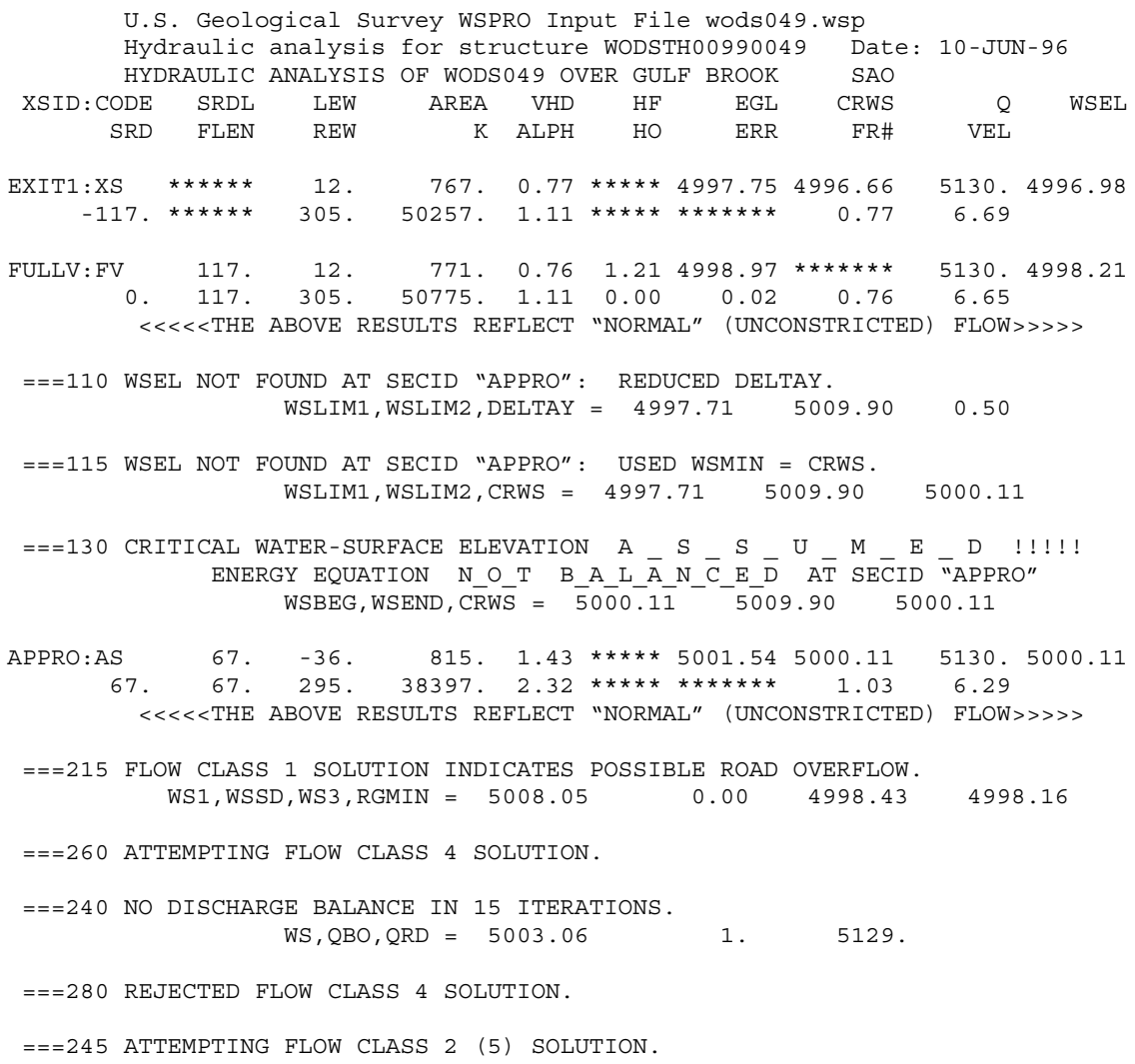


WSPRO OUTPUT FILE (continued)

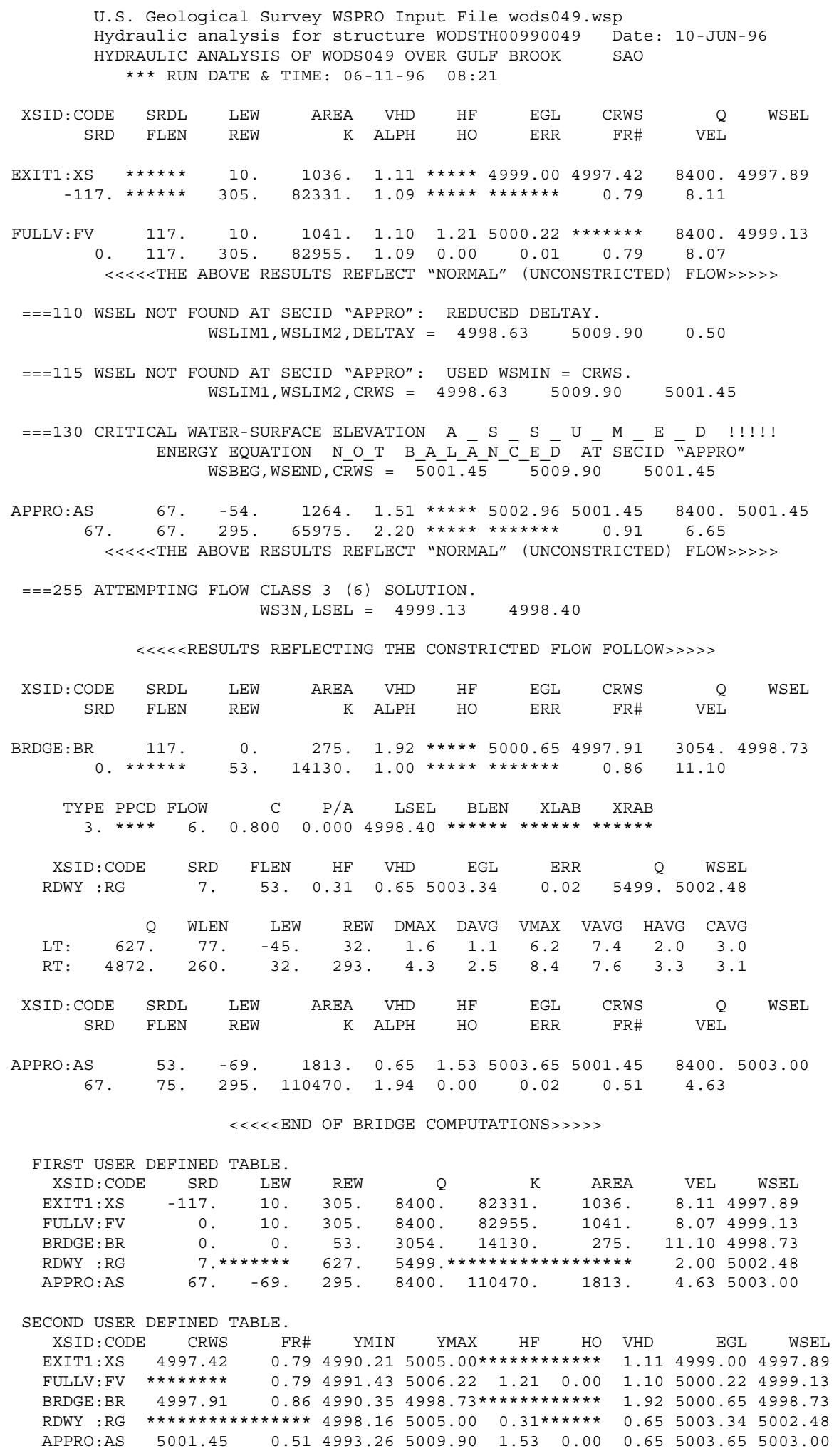


WSPRO OUTPUT FILE (continued)

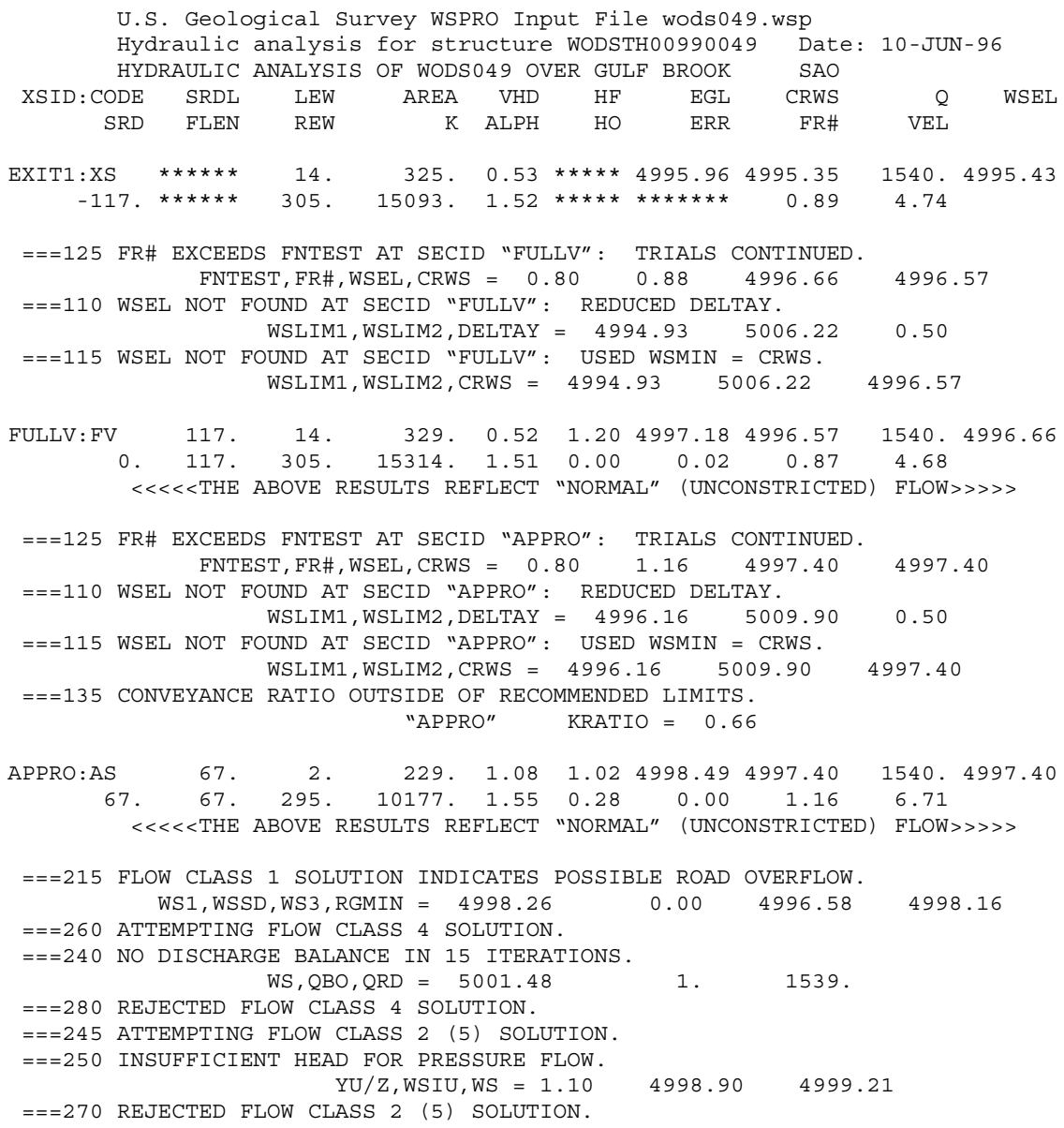




\section{APPENDIX C:}

\section{BED-MATERIAL PARTICAL-SIZE DISTRIBUTION}




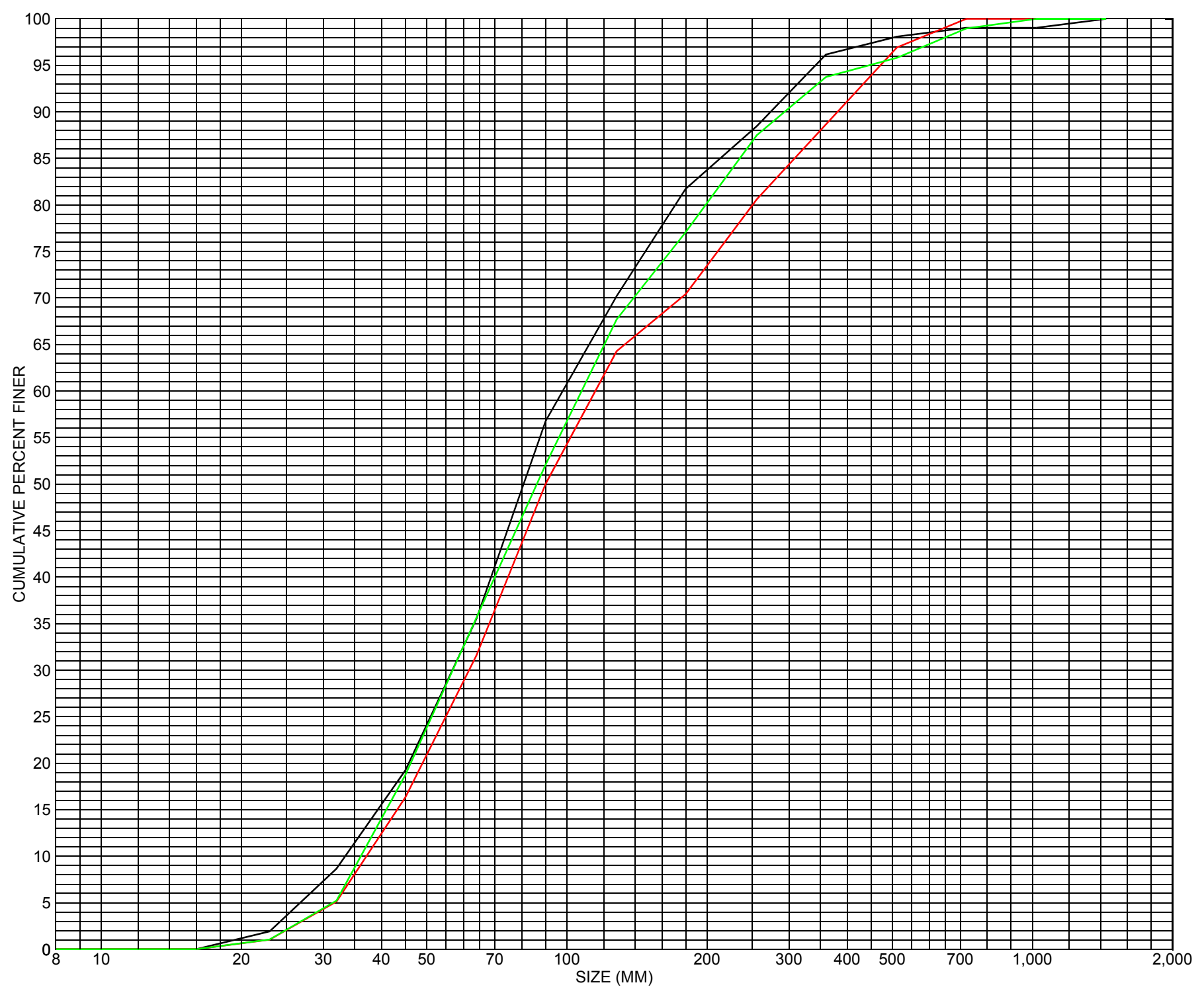

Appendix C. Bed material particle-size distribution for three pebble count transects in the channel approach of structure WODSTH00990049, in Woodstock, Vermont. 


\section{APPENDIX D: \\ HISTORICAL DATA FORM}




\section{Structure Number WODSTH00990049}

\section{General Location Descriptive}

Data collected by (First Initial, Full last name) $\mathbf{M}$. IVANOFF

Date $(M M / D D / Y Y) \_\mathbf{0 4} / \underline{04} / \underline{95}$

Highway District Number (I - 2; nn) $\mathbf{0 4}$

Town (FIPS place code; I - 4; nnnnn) $\mathbf{8 5 9 7 5}$

Waterway (I - 6) GULF BROOK

Route Number TH099

Topographic Map Woodstock.North

Latitude (I - 16; nnnn.n) $\mathbf{4 3 3 8 8}$
County (FIPS county code; I - 3; nnn) $\underline{\mathbf{0 2 7}}$

Mile marker (I - 11; nnn.nnn) $\mathbf{0 0 0 0 0 0}$

Road Name (I - 7): -

Vicinity (I - 9) $\mathbf{0 . 0 5}$ MI JCT TH 99 + VT12

Hydrologic Unit Code: $\mathbf{0 1 0 8 0 1 0 6}$

Longitude (i - 17; nnnnn.n) $\mathbf{7 2 3 2 2}$

\section{Select Federal Inventory Codes}

FHWA Structure Number (I - 8) $\mathbf{1 0 1 4 2 4 0 0 4 9 1 4 2 4}$

Maintenance responsibility $(I-21 ; n n) \quad \mathbf{0 3}$

Year built (I - 27; YYYY) 1955

Average daily traffic, ADT (I - 29; nnnnnn) 000050

Year of ADT (I - 30; YY) $\mathbf{9 0}$

Opening skew to Roadway $(I-34 ; n n) \quad \mathbf{0 0}$

Operational status $(I-41 ; X) \mathbf{P}$

Structure type (I - 43; nnn) $\mathbf{3 0 2}$

Approach span structure type $(I-44 ; n n n)$ 000

Number of spans (I - 45; nnn) $\mathbf{0 0 1}$

Number of approach spans (I - 46; nnnn) $\mathbf{0 0 0 0}$

Comments:

The structural inspection report of $08 / 19 / 94$ indicates the structure is a steel stringer type bridge with a timber deck. The right road approach has a crushed stone wearing surface. The route VT 12 intersects on the left approach. The concrete abutment walls have very minor stains reported. There is good stone block riprap placed along both abutments. The footings reportedly are not in view. The waterway takes a slight turn through the structure with the majority of the flow proceeding along the right abutment side of the channel. There is a shallow gravel point bar along the left abutment. The streambed consists of stone and gravel.
Maximum span length (I - 48; nnnn) $\underline{0055}$

Structure length (I - 49; nnnnnn) $\underline{000056}$

Deck Width (I - 52; nn.n) 140

Channel \& Protection $(I-61 ; n) \underline{6}$

Waterway adequacy $(I-71 ; n) \underline{5}$

Underwater Inspection Frequency $(I-92 B ; X Y Y) \_$N

Year Reconstructed (I - 106) 1968

Clear span (nnn.n ft)

Vertical clearance from streambed (nnn.n ft)

Waterway of full opening (nnn.n $\left.\mathrm{ft}^{2}\right)$ 


\section{Bridge Hydrologic Data}

Is there hydrologic data available? $\underline{\mathbf{N}}$ if No, type ctrl-n $h \quad$ VTAOT Drainage area $\left(m i^{2}\right)$ : -

Terrain character:

Stream character \& type: -

Streambed material:

Discharge Data (cfs):

$$
\begin{aligned}
& Q_{2.33}- \\
& Q_{50}-
\end{aligned}
$$

Record flood date $(M M / D D / Y Y)$ :

Estimated Discharge (cfs): Ice conditions (Heavy, Moderate, Light) : -

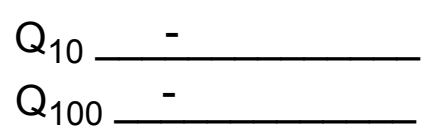

$$
\begin{aligned}
& Q_{25}- \\
& Q_{500}-
\end{aligned}
$$

Water surface elevation $(f t):-$

The stage increases to maximum highwater elevation (Rapidly, Not rapidly):

The stream response is (Flashy, Not flashy):

Describe any significant site conditions upstream or downstream that may influence the stream's stage: -

Watershed storage area (in percent): _ _ \%

The watershed storage area is: - (1-mainly at the headwaters; 2- uniformly distributed; 3-immediatly upstream oi the site)

Water Surface Elevation Estimates for Existing Structure:

\begin{tabular}{|l|l|l|l|l|l|}
\hline Peak discharge frequency & $Q_{2.33}$ & $Q_{10}$ & $Q_{25}$ & $Q_{50}$ & $Q_{100}$ \\
Water surface elevation (ft)) & - & - & - & - & - \\
Velocity (ft/sec) & - & - & - & - & - \\
\hline
\end{tabular}

Long term stream bed changes: -

Is the roadway overtopped below the $\mathrm{Q}_{100}$ ? (Yes, No, Unknown): $\mathbf{U}$ Frequency: Relief Elevation (ft): Discharge over roadway at $Q_{100}\left(f^{3} / \mathrm{sec}\right)$ :

Are there other structures nearby? (Yes, No, Unknown): $\underline{\mathbf{U}}$ Upstream distance (miles): Town: If No or Unknown, type ctrl-n os Highway No. : Structure No. : Year Built:

Clear span (ft): Clear Height $(f t)$ : Full Waterway $\left(f^{2}\right)$ : 
Downstream distance (miles): Town: Year Built:

Highway No. : Structure No. : Structure Type:

Clear span (ft): Clear Height $(f t)$ : Full Waterway $\left(f t^{2}\right)$ :

Comments:

\section{USGS Watershed Data}

Watershed Hydrographic Data

Drainage area $(D A) \quad 16.77 \quad \mathrm{mi}^{2}$

Watershed storage (ST) 0.2

Bridge site elevation $\lcm{\mathbf{7 2 0}} \mathrm{ft}$ $\%$

Main channel length $\mathbf{8 . 4}$ mi

$10 \%$ channel length elevation 790 $\mathrm{ft} \quad 85 \%$ channel length elevation $\mathrm{ft}$

Main channel slope $(S)$

(S) 176.0 $\mathrm{ft} / \mathrm{mi}$

Watershed Precipitation Data

Average site precipitation in

Average headwater precipitation in

Maximum 2yr-24hr precipitation event $(124,2)$ in

Average seasonal snowfall (Sn) $\mathrm{ft}$ 


\section{Bridge Plan Data}

Are plans available? $\mathbf{Y} \quad$ If no, type ctrl-n $p / \quad$ Date issued for construction (MM/YYYY): - / 1954 Project Number T 12 / $1954 \quad$ Minimum channel bed elevation: 712.0

Low superstructure elevation: USLAB $\underline{\mathbf{7 1 8 . 6}}$ DSLAB $\underline{\mathbf{7 1 8 . 6}}$ USRAB $\underline{\mathbf{7 1 8 . 0 6}}$ DSRAB $\underline{\mathbf{7 1 8 . 0 6}}$ Benchmark location description:

NO BENCHMARK INFORMATION

Reference Point (MSL, Arbitrary, Other): Arbitrary $\quad$ Datum (NAD27, NAD83, Other): Foundation Type: 1

If 1: Footing Thickness _ _ Footing bottom elevation: $\mathbf{7 1 4 . *}$

If 2: Pile Type:___ (1-Wood; 2-Steel or metal; 3-Concrete) Approximate pile driven length:

If 3: Footing bottom elevation:

Is boring information available? $\mathbf{N}$ If no, type ctrl- $n$ bi Number of borings taken: _-

Foundation Material Type: $\mathbf{3}$ (1-regolith, 2-bedrock, 3-unknown)

Briefly describe material at foundation bottom elevation or around piles:

NO FOUNDATION MATERIAL INFORMATION

\section{Comments:}

*The footing bottom elevations are 714.10 and 713.56 for the left and right abutments respectively. 


\section{Cross-sectional Data}

Is cross-sectional data available? $\mathbf{N}$ If no, type ctrl-n xs

Source (FEMA, VTAOT, Other)? -

Comments: NO CROSS SECTION INFORMATION

\begin{tabular}{|l|l|l|l|l|l|l|l|l|l|l|l|}
\hline Station & - & - & - & - & - & - & - & - & - & - & - \\
\hline Feature & - & - & - & - & - & - & - & - & - & - & - \\
\hline $\begin{array}{l}\text { Low cord } \\
\text { elevation }\end{array}$ & - & - & - & - & - & - & - & - & - & - & - \\
\hline $\begin{array}{l}\text { Bed } \\
\text { elevation }\end{array}$ & - & - & - & - & - & - & - & - & - & - & - \\
\hline $\begin{array}{l}\text { Low cord to } \\
\text { bed length }\end{array}$ & - & - & - & - & - & - & - & - & - & - & - \\
\hline Station & - & - & - & - & - & - & - & - & - & - & - \\
\hline Feature & - & - & - & - & - & - & - & - & - & - & - \\
\hline $\begin{array}{l}\text { Low cord } \\
\text { elevation }\end{array}$ & - & - & - & - & - & - & - & - & - & - & - \\
\hline $\begin{array}{l}\text { Bed } \\
\text { elevation }\end{array}$ & - & - & - & - & - & - & - & - & - & - & - \\
\hline $\begin{array}{l}\text { Low cord to } \\
\text { bed length }\end{array}$ & - & - & - & - & - & - & - & - & - & - & - \\
\hline
\end{tabular}

Source (FEMA, VTAOT, Other)?

Comments: NO CROSS SECTION INFORMATION

\begin{tabular}{|l|l|l|l|l|l|l|l|l|l|l|l|}
\hline Station & - & - & - & - & - & - & - & - & - & - & - \\
\hline Feature & - & - & - & - & - & - & - & - & - & - & - \\
\hline $\begin{array}{l}\text { Low cord } \\
\text { elevation }\end{array}$ & - & - & - & - & - & - & - & - & - & - & - \\
\hline $\begin{array}{l}\text { Bed } \\
\text { elevation }\end{array}$ & - & - & - & - & - & - & - & - & - & - & - \\
\hline $\begin{array}{l}\text { Low cord to } \\
\text { bed length }\end{array}$ & - & - & - & - & - & - & - & - & - & - & - \\
\hline Station & - & - & - & - & - & - & - & - & - & - & - \\
\hline Feature & - & - & - & - & - & - & - & - & - & - & - \\
\hline $\begin{array}{l}\text { Low cord } \\
\text { elevation }\end{array}$ & - & - & - & - & - & - & - & - & - & - & - \\
\hline $\begin{array}{l}\text { Bed } \\
\text { elevation }\end{array}$ & - & - & - & - & - & - & - & - & - & - & - \\
\hline $\begin{array}{l}\text { Low cord to } \\
\text { bed length }\end{array}$ & - & - & - & - & - & - & - & - & - & - & - \\
\hline
\end{tabular}




\section{APPENDIX E: \\ LEVEL I DATA FORM}


U. S. Geological Survey

Bridge Field Data Collection and Processing Form

Qa/Qc Check by: MAI Date: $2 / 15 / 95$

\section{A. General Location Descriptive}

1. Data collected by (First Initial, Full last name) $\mathbf{R}$. HAMMOND

Date $(M M / D D / Y Y) \quad 09 / 15 / 1994$

2. Highway District Number 4

County WINDSOR

Waterway (I - 6) GULF STREAM

Route Number TH099

3. Descriptive comments:

LOCATED 0.05 MILES FROM JUNCTION OF TOWN HIGHWAY 99 AND STATE HIGHWAY 12.

SITE REVISITED ON 12/14/94 BY M. WEBER TO SUPPLEMENT DATA COLLECTED ON 9/15/94.
Mile marker $\mathbf{0}$

Town WOODSTOCK

Road Name -

Hydrologic Unit Code: $\mathbf{0 1 0 8 0 1 0 6}$

\section{B. Bridge Deck Observations}
4. Surface cover... LBUS 4
RBUS 5
LBDS 4
RBDS 4
Overall 4

(2b us,ds,lb,rb: 1- Urban; 2- Suburban; 3- Row crops; 4- Pasture; 5- Shrub- and brushland; 6- Forest; 7- Wetland)
5. Ambient water surface... US $\underline{2}$
UB 1
DS 2
(1- pool; 2- riffle)

6. Bridge structure type 1 (1- single span; 2- multiple span; 3- single arch; 4- multiple arch; 5-cylindrical culvert; 6- box culvert; or 7- other)
7. Bridge length $\mathbf{5 6}$ (feet)
Span length $\underline{\mathbf{5 5}}$
(feet)
Bridge width 14 (feet)

\section{Road approach to bridge:}
8. LB
RB 0
( 0 even, 1- lower, 2- higher)
9. LB 1
RB $\underline{2}$
(1- Paved, 2- Not paved)

10. Embankment slope (run / rise in feet / foot):

US left $4: 1$

US right -

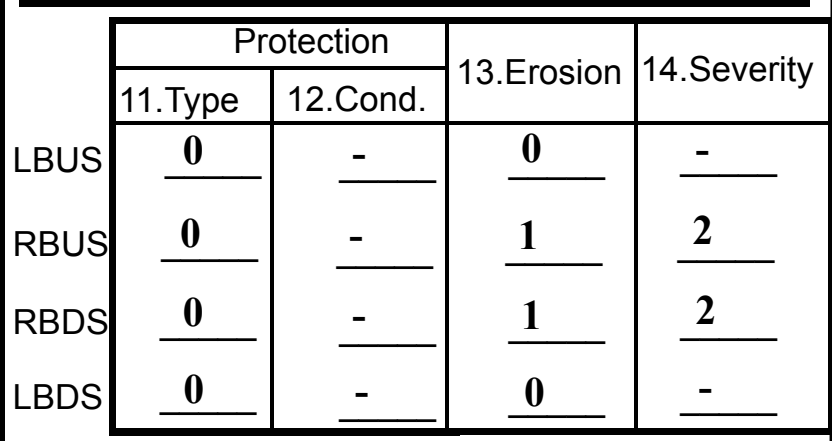

Bank protection types: 0- none; 1- $<12$ inches;

2- < 36 inches; 3- < 48 inches;

4- < 60 inches; 5- wall / artificial levee

Bank protection conditions: 1- good; 2- slumped;

3- eroded; 4- failed

Erosion: 0 - none; 1- channel erosion; 2-

road wash; 3- both; 4- other

Erosion Severity: 0 - none; 1- slight; 2- moderate;

\section{Channel approach to bridge (BF):}

15. Angle of approach: $\mathbf{2 0}$

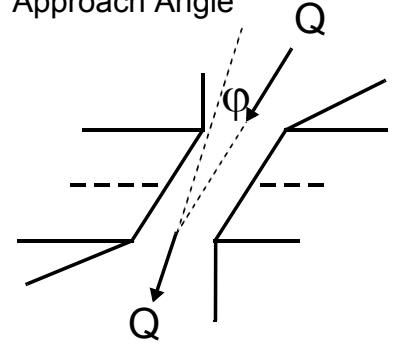

17. Channel impact zone 1:

Where? RB (LB, RB)

Range? 35 feet US

Channel impact zone 2:

Where? - $\quad(L B, R B)$

Range? - $\quad$ feet -

(US, UB, DS) to -

Impact Severity: 0- none to very slight; 1-Slight; 2- Moderate; 3- Severe feet -

16. Bridge skew: 20

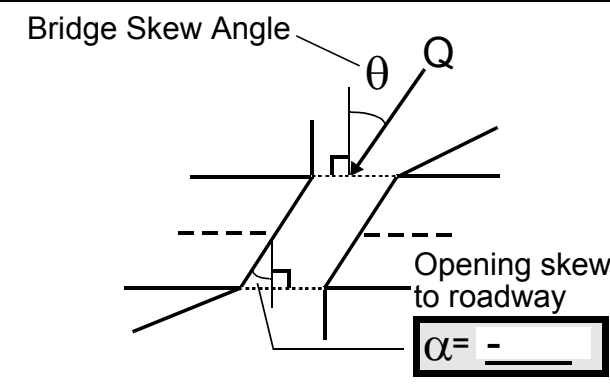

Exist? $\mathbf{Y}(Y$ or $N)$

Severity 2

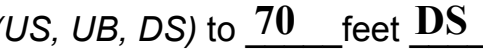

Exist? $\underline{\mathbf{N}}(\mathrm{Y}$ or $N)$

Severity - 
18. Bridge Type: $\mathbf{3}$

1a- Vertical abutments with wingwalls

1 b- Vertical abutments without wingwalls

2- Vertical abutments and wingwalls, sloping embankment

Wingwalls perpendicular to abut. face

3- Spill through abutments

4- Sloping embankment, vertical wingwalls and abutments

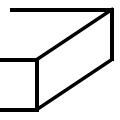

1a with wingwalls

Wingwall angle less than $90^{\circ}$.

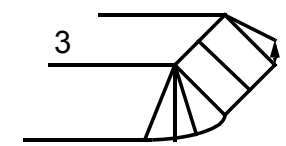

19. Bridge Deck Comments (surface approach overflow width, etc.)

\section{LARGE QUARRIED STONE ON SPILL-THROUGH SLOPE OF BOTH ABUTMENTS. VERMONT ROUTE 12 IS PARALLEL TO LEFT BANK OF GULF STREAM IN THE VICINITY OF THE BRIDGE.}

\section{Upstream Channel Assessment}

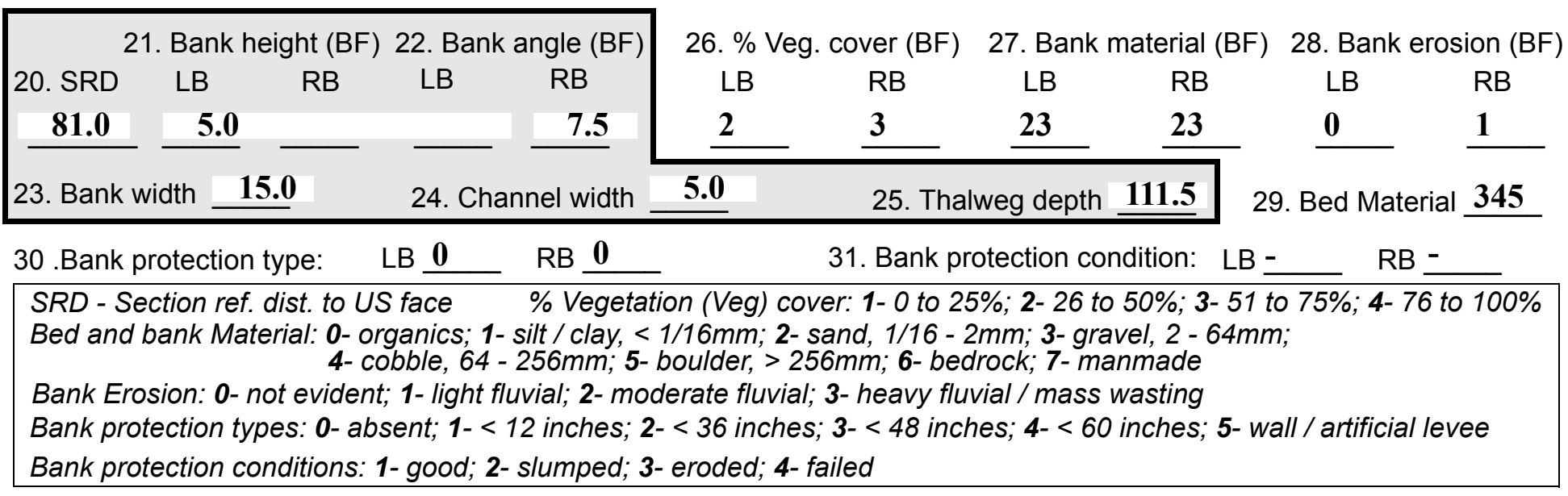

32. Comments (bank material variation, minor inflows, protection extent, etc.):

RIGHT ABUTMENT PROTUDES INTO CHANNEL NEARLY 10 FEET. 
36. Point bar extent: 250 feet $\underline{\mathbf{U S}}$ (US, UB) to $\underline{\mathbf{5 5}}$ feet $\underline{\mathbf{D S}}$ (US, UB, DS) positioned $\underline{\mathbf{0}} \%$ LB to $\underline{\mathbf{2 5}} \%$

37. Material: 23

38. Point or side bar comments (Circle Point or Side; Note additional bars, material variation, status, etc.):

39. Is a cut-bank present? $\mathbf{Y}$ (Y or if $N$ type $c t r l-n c b)$

41. Mid-bank distance: $\mathbf{2 0}$

43. Bank damage: 1

42. Cut bank extent: $\mathbf{5 5}$
40. Where? RB (LB or RB) feet US (US, UB) to 15 feet $\underline{\mathbf{U S}}$ (US, UB, DS)

44. Cut bank comments (eg. additional cut banks, protection condition, etc.):

45. Is channel scour present? $\mathbf{Y}$ Width 9 ( $Y$ or if $N$ type ctrl-n cs)

47. Scour dimensions: Length $\underline{43}$ Depth : 1.3
46. Mid-scour distance: 25

Position $\underline{\mathbf{7 5}} \%$ LB to $\underline{\mathbf{1 0 0}} \% \mathrm{RB}$

48. Scour comments (eg. additional scour areas, local scouring process, etc.):

49. Are there major confluences? $\mathbf{N}$

51. Confluence 1: Distance Confluence 2: Distance 52. Enters on Enters on -

54. Confluence comments (eg. confluence name):
50. How many? -

53. Type(1- perennial; 2- ephemeral)

Type (1- perennial; 2- ephemeral)

\section{Under Bridge Channel Assessment}

55. Channel restraint (BF)? LB 2

56. Height (BF)
LB RB
$\mathbf{2 8 . 5}-$
58. Bank width (BF) -
59. Channel width (Amb) (1- natural bank; 2- abutment; 3- artificial levee)

Bed and bank Material: 0- organics; 1- silt / clay, < 1/16mm; 2- sand, 1/16 - 2mm; 3- gravel, 2 - 64mm; 4- cobble, 64 - 256mm; 5- boulder, > 256mm; 6- bedrock; 7- manmade

Bank Erosion: 0- not evident; 1- light fluvial; 2- moderate fluvial; 3- heavy fluvial / mass wasting

64. Comments (bank material variation, minor inflows, protection extent, etc.):

324 
65. Debris and Ice Is there debris accumulation? $(Y$ or $N)$ 66. Where? $\underline{\mathbf{n}}$ (1- Upstream; 2- At bridge; 3- Both)

67. Debris Potential ( 1-Low; 2- Moderate; 3- High) 68. Capture Efficiency 1 (1-Low; 2- Moderate; 3- High) 69. Is there evidence of ice build-up? 2 (Y or $N)$ Ice Blockage Potential $\underline{\mathbf{N}}$ (1-Low; 2- Moderate; 3- High) 70. Debris and Ice Comments: 1

\section{RIFFLES US AND DS, SOME CONSTRICTION UNDER THE BRIDGE AND A RELATIVELY LOW} LOW CHORD RESULTS IN A MODERATE CAPTURE EFFICIENCY.

\begin{tabular}{|l|l|l|l|l|c|c|c|c|}
\hline Abutments & $\begin{array}{c}\text { 71. Attack } \\
\angle \text { (BF) }\end{array}$ & $\begin{array}{c}\text { 72. Slope } \angle \\
\text { (Qmax) }\end{array}$ & $\begin{array}{c}\text { 73. Toe } \\
\text { loc. (BF) }\end{array}$ & $\begin{array}{c}\text { 74. Scour } \\
\text { Condition }\end{array}$ & $\begin{array}{c}75 . \text { Scour } \\
\text { depth }\end{array}$ & $\begin{array}{c}\text { 76. Exposure } \\
\text { depth }\end{array}$ & 77. Material & 78. Length \\
\hline LABUT & & - & $\mathbf{4 0}$ & $\mathbf{2}$ & $\mathbf{0}$ & - & - & - \\
\hline RABUT & $\mathbf{1 , 2}$ & $\mathbf{2 0}$ & $\mathbf{4 0}$ & & & $\mathbf{2}$ & $\mathbf{1}$ & $\mathbf{5 3 . 0}$ \\
\hline
\end{tabular}

Pushed: $L B$ or RB

Toe Location (Loc.): 0- even, 1- set back, 2- protrudes

Scour cond.: 0- not evident; 1- evident (comment); 2- footing exposed; 3-undermined footing; 4- piling exposed; 5- settled; 6- failed

Materials: 1- Concrete; 2- Stone masonry or drywall; 3- steel or metal; 4- wood

79. Abutment comments (eg. undermined penetration, unusual scour processes, debris, etc.):

2.0

$<1$

1,2

76. SCOUR AT BASE OF RIGHT ABUTMENT. TOE OF SPILL-THROUGH SLOPE OF LARGE QUARRIED STONE (3FTX3FTX2FT) IS UNDERMINED IN SOME LOCATIONS. UNDERMINING IS LESS THAN A FOOT. HORIZONTAL PENETRATION UNDER THE STONE IS O.5 FT. THERE IS NO APPARENT MOVEMENT OF THE STONE SPILL-THROUGH SLOPE.

\section{ABUTMENTS ARE CONCRETE WITH A STONE SPILL-THROUGH SLOPE.}

80. Wingwalls:

$\begin{array}{llll}\text { Exist? Material? } & \text { Scour } & \text { Scour Exposure } & \text { Angle? Length? } \\ & \text { Condition? depth? } & \text { depth? }\end{array}$

USLWW:

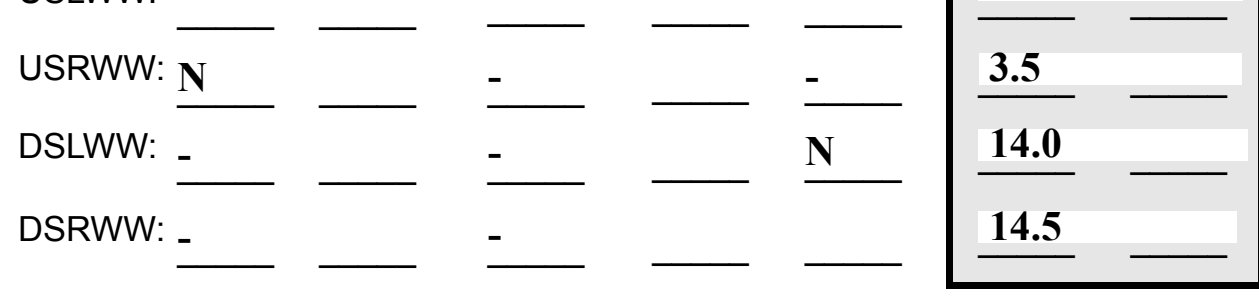

Wingwall materials: 1- Concrete; 2- Stone masonry or drywall; 3- steel or metal; 4- wood

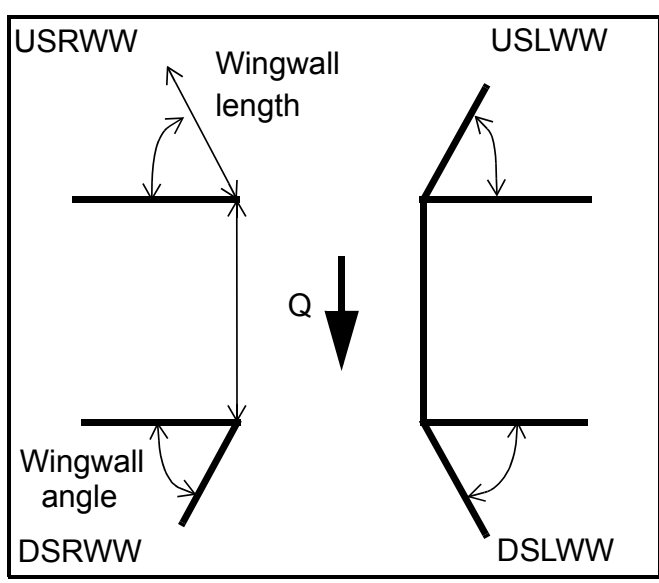

82. Bank / Bridge Protection:

\begin{tabular}{|l|l|l|l|l|l|l|l|c|}
\hline Location & USLWW & USRWW & LABUT & RABUT & LB & RB & DSLWW & DSRWW \\
\hline Type & - & - & N & - & - & - & $\mathbf{1}$ & $\mathbf{1}$ \\
\hline Condition & $\mathbf{N}$ & - & - & - & - & - & $\mathbf{3}$ & $\mathbf{3}$ \\
\hline Extent & - & - & - & - & - & $\mathbf{3}$ & $\mathbf{3}$ & - \\
\hline
\end{tabular}

Bank / Bridge protection types: 0- absent; 1-<12 inches; 2- < 36 inches; 3- < 48 inches; 4- < 60 inches; 
83. Wingwall and protection comments (eg. undermined penetration, unusual scour processes, etc.):

-
-
-
-
-
-
-
-
-
-

\section{Piers:}

84. Are there piers? $\mathbf{T H}$ (Y or if $N$ type ctrl-n pr)

\begin{tabular}{|l|l|l|l|l|l|l|l|}
\hline \multirow{2}{*}{$\begin{array}{l}85 . \\
\text { Pier no. }\end{array}$} & \multicolumn{3}{|c|}{ width (w) feet } & \multicolumn{3}{c|}{ elevation (e) feet } \\
\cline { 2 - 9 } & w1 & w2 & w3 & e@w1 & e@w2 & e@w3 \\
\hline Pier 1 & - & - & - & - & - & - \\
\hline Pier 2 & - & - & - & - & - & - \\
\hline Pier 3 & - & - & - & - & - & - & - \\
\hline Pier 4 & - & - & - & - & - & w1 \\
\hline
\end{tabular}

\begin{tabular}{|l|l|l|l|l|}
\hline Level 1 Pier Descr. & \multicolumn{1}{|c|}{1} & \multicolumn{1}{|c|}{2} & \multicolumn{1}{|c|}{3} & 4 \\
\hline 86. Location (BF) & E & THR & ABU & \\
\hline 87. Type & QUA & OU & TM & \\
\hline 88. Material & RRI & GH & ENT & \\
\hline 89. Shape & ED & SLO & PRO & \\
\hline 90. Inclined? & STO & PE & TEC & N \\
\hline 91. Attack $\angle$ (BF) & NE & IS & TIO & - \\
\hline 92. Pushed & USE & ALS & N. & - \\
\hline 93. Length (feet) & - & - & - & - \\
\hline 94. \# of piles & D & O & & - \\
\hline 95. Cross-members & FOR & CON & & - \\
\hline 96. Scour Condition & THE & SID- & & - \\
\hline 97. Scour depth & SPIL & ERE & & - \\
\hline 98. Exposure depth & L- & D AS & & - \\
\hline
\end{tabular}

LFP, LTB, LB, MCL, MCM, MCR, RB, RTB, RFP

1- Solid pier, 2- column, 3- bent

1-Wood; 2- concrete; 3- metal; 4- stone

1- Round; 2- Square; 3- Pointed

Y-yes; $N$ - no

$L B$ or $R B$

0- none; 1- laterals; 2- diagonals; 3- both

0- not evident; 1- evident (comment);

2- footing exposed; 3- piling exposed;

4- undermined footing; 5- settled; 6- failed 
99. Pier comments (eg. undermined penetration, protection and protection extent, unusual scour processes, etc.):

-
-
-
-
-
-
-
-
-

100.

\section{E. Downstream Channel Assessment}

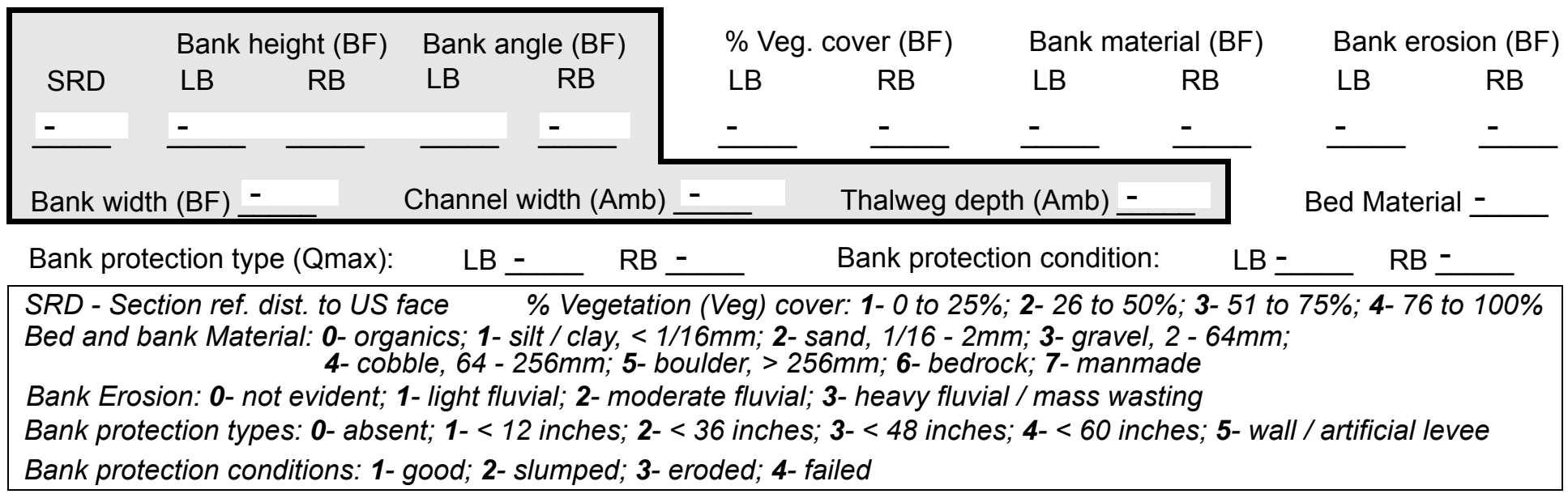

Comments (eg. bank material variation, minor inflows, protection extent, etc.):

$-$

$-$

$-$

$-$

-

$-$

$-$

$-$

-

-

-

-

-

-

-

101. Is a drop structure present? _ ( $Y$ or $N$, if $N$ type ctrl-n ds) 102. Distance: __ feet
103. Drop: - feet
104. Structure material:
(1- steel sheet pile; 2- wood pile; 3-concrete; 4- other)

105. Drop structure comments (eg. downstream scour depth):

$-$

$-$

-

\section{NO PIERS}


106. Point/Side bar present? (Y or $N$. if $N$ type ctrl-n pb)Mid-bar distance:

Mid-bar width:

Point bar extent: feet

(US, UB, DS) to feet (US, UB, DS) positioned 1 \%LB to 1 \%RB

Point or side bar comments (Circle Point or Side; note additional bars, material variation, status, etc.):

\section{3}

0

2

324

Is a cut-bank present? 0 (Y or if $N$ type ctrl-n cb) Where? $\underline{\mathbf{2}}$ (LB or RB) Mid-bank distance: Cut bank extent: 1 feet ___ (US, UB, DS) to ___ feet ___ (US, UB, DS)

Bank damage: ___ (1- eroded and/or creep; 2- slip failure; 3- block failure)

Cut bank comments (eg. additional cut banks, protection condition, etc.):

Is channel scour present? ( $Y$ or if $N$ type ctrl-n cs)

Mid-scour distance:

Scour dimensions: Length Width Depth:

Positioned $\%$ LB to $\% \mathrm{RB}$ Scour comments (eg. additional scour areas, local scouring process, etc.):

$\mathbf{N}$

$-$

NO DROP STRUCTURE

Are there major confluences? ( $Y$ or if $N$ type ctrl-n $m c)$

How many?

Confluence 1: Distance Enters on ( $L B$ or $R B)$

Type $\mathbf{Y}$ (1- perennial; 2- ephemeral)

Confluence 2: Distance Enters on (LB or $R B)$

Type (1-perennial; 2- ephemeral)

Confluence comments (eg. confluence name):

\section{F. Geomorphic Channel Assessment}

107. Stage of reach evolution -

1- Constructed

2- Stable

3- Aggraded

4- Degraded

5- Laterally unstable

6- Vertically and laterally unstable 
108. Evolution comments (Channel evolution not considering bridge effects; See HEC-20, Figure 1 for geomorphic descriptors):

-

$-$

POINT BAR IN UPSTREAM SECTION DATA EXTENDS DOWNSTREAM.

Y

RB

25

25

DS

75 


\begin{tabular}{|c|c|c|c|}
\hline & 109. & Plan View Sketch & \\
\hline $\begin{array}{l}\text { point bar } \\
\text { cut-bank } \\
\text { scour hole }\end{array}$ & debris & $\begin{array}{l}\text { flow } \stackrel{Q}{\longrightarrow} \\
\text { cross-section }+|+|+1 \\
\text { ambient channel }-\end{array}$ & $\begin{array}{l}\text { stone wall } \square \square \square \square \\
\text { other wall } \square\end{array}$ \\
\hline
\end{tabular}


APPENDIX F:

SCOUR COMPUTATIONS 
SCOUR COMPUTATIONS

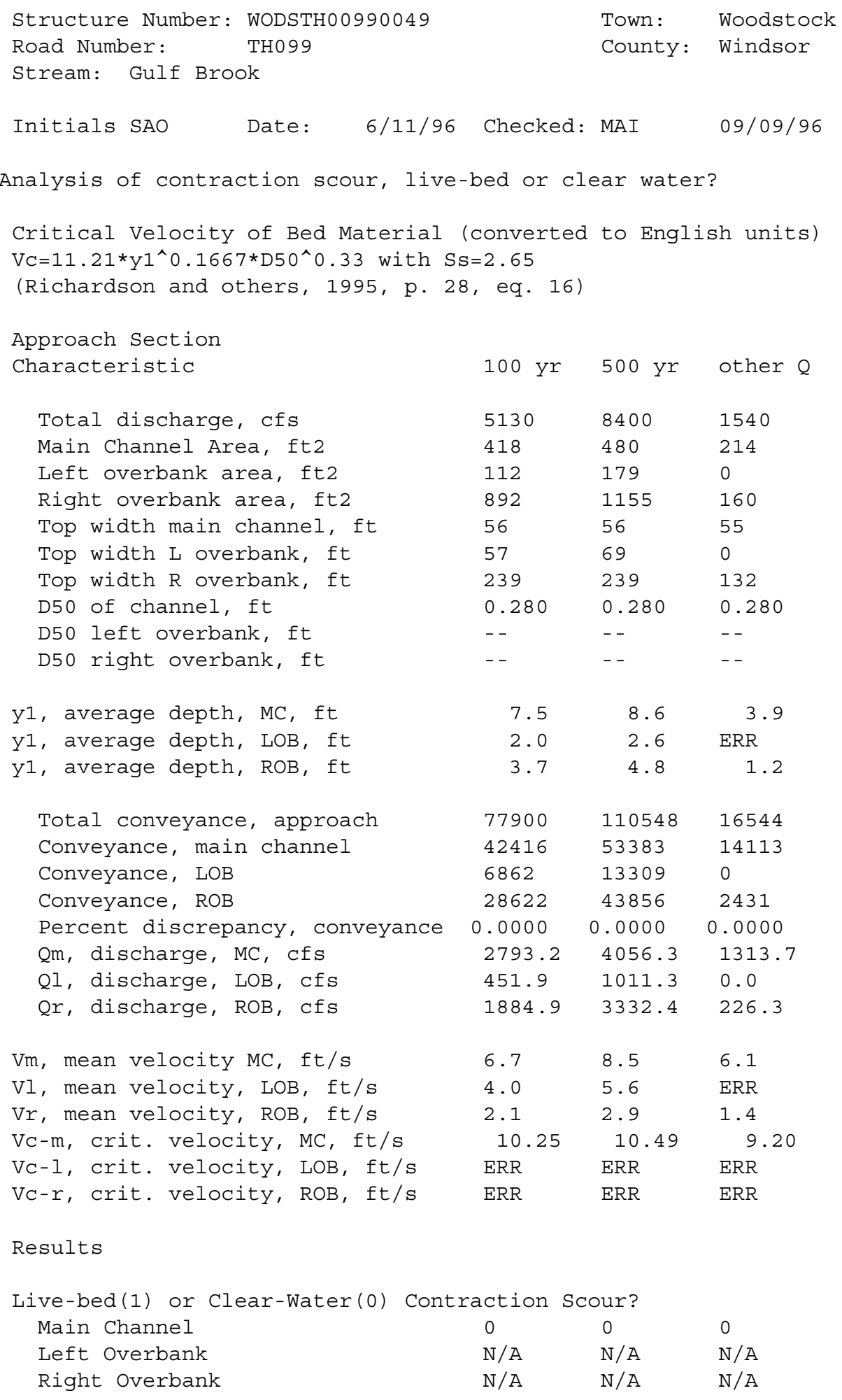


Clear Water Contraction Scour in MAIN CHANNEL

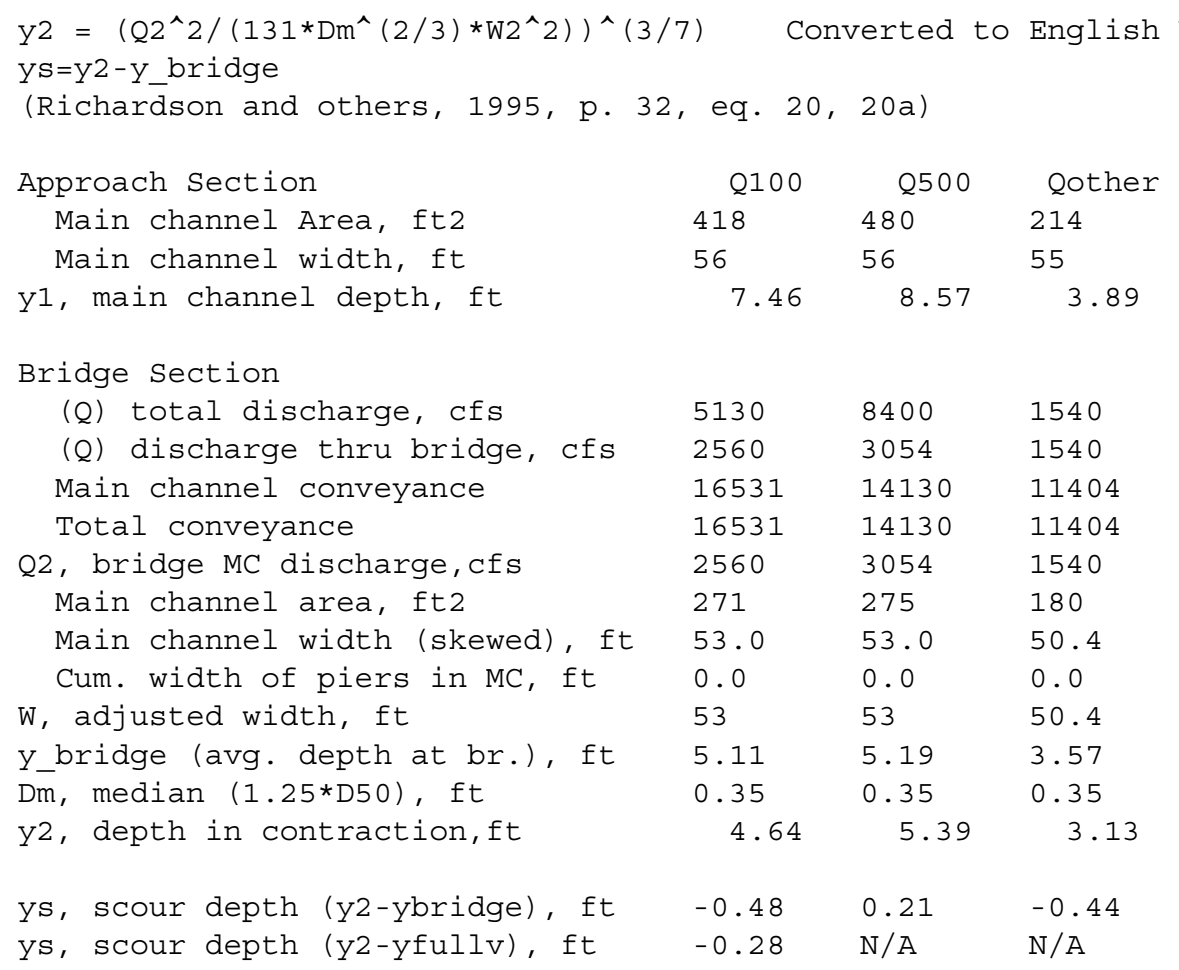

Pressure Flow Scour (contraction scour for orifice flow conditions)

\begin{tabular}{|c|c|c|c|}
\hline $\mathrm{Hb}+\mathrm{Ys}=\mathrm{Cq}{ }^{*} \mathrm{qb} r / \mathrm{Vc}$ & $C f=1$ & $5 * F r^{\wedge} 0.4$ & $(<=1)$ \\
\hline $\begin{array}{l}\text { Chang Equation CC=SQRT }[0.1 \\
\text { (Richardson and others, 1995, p. }\end{array}$ & $\begin{array}{l}\mathrm{Hb} /(\mathrm{ya}-\mathrm{w}) \\
5-146)\end{array}$ & $-0.56)]+0$ & $(<=1)$ \\
\hline & Q100 & Q500 & OtherQ \\
\hline Q thru bridge main chan, cfs & 2560 & 3054 & 0 \\
\hline Vc, critical velocity, ft/s & 10.25 & 10.49 & 0 \\
\hline Vc, critical velocity, m/s & 3.124048 & 3.197196 & 0 \\
\hline Main channel width (skewed), ft & 53 & 53 & 0 \\
\hline Cum. width of piers, ft & 0 & 0 & 0 \\
\hline w, adjusted width, ft & 53 & 53 & 0 \\
\hline qbr, unit discharge, $f t^{\wedge} 2 / \mathrm{s}$ & 48.30189 & 57.62264 & ERR \\
\hline qbr, unit discharge, $\mathrm{m}^{\wedge} 2 / \mathrm{s}$ & 4.486954 & 5.352796 & $\mathrm{~N} / \mathrm{A}$ \\
\hline Area of full opening, $\mathrm{ft}^{\wedge} 2$ & 270.8 & 275.1 & 0 \\
\hline $\mathrm{Hb}$, depth of full opening, ft & 5.109434 & 5.190566 & ERR \\
\hline Hb, depth of full opening, m & 1.557279 & 1.582007 & $\mathrm{~N} / \mathrm{A}$ \\
\hline Fr, Froude number MC & 0.74 & 0.86 & 1 \\
\hline Cf, Fr correction factor $(<=1.0)$ & 1 & 1 & 1.5 \\
\hline Elevation of Low Steel, ft & 4998.4 & 4998.4 & 0 \\
\hline
\end{tabular}


Elevation of Bed, ft

Elevation of approach WS, ft

$\mathrm{HF}$, bridge to approach, ft

Elevation of WS immediately US, ft

ya, depth immediately US, ft

ya, depth immediately US, m

Mean elev. of deck, ft

$w$, depth of overflow, ft $(>=0)$

Cc, vert contrac correction ( $<=1.0)$

Ys, depth of scour (chang), ft
$4993.2914993 .209 \mathrm{~N} / \mathrm{A}$

$5001.9 \quad 5003 \quad 0$

$0.83 \quad 1.53 \quad 0$

$5001.07 \quad 5001.47 \quad 0$

$7.7794348 .260566 \mathrm{~N} / \mathrm{A}$

$2.4174752 .566988 \mathrm{~N} / \mathrm{A}$

$5000.94 \quad 5000.94 \quad 0$

$0.13 \quad 0.53 \quad 0$

$0.8938990 .895562 \mathrm{ERR}$

$0.1622810 .943124 \mathrm{~N} / \mathrm{A}$

$\begin{array}{llll}\text { ARMORING } & & & \\ \text { D90 } & 1.031 & 1.031 & 1.031 \\ \text { D95 } & 1.413 & 1.413 & 1.413 \\ \text { Critical grain size,DC, ft } & 0.5343 & 0.7333 & 0.5262 \\ \text { Decimal-percent coarser than DC } & 0.262 & 0.179 & 0.266 \\ \text { Depth to armoring,ft } & 4.52 & 10.09 & 4.36\end{array}$

Abutment Scour

Froehlich's Abutment Scour

$\mathrm{Ys} / \mathrm{Y} 1=2.27 * \mathrm{~K} 1 * \mathrm{~K} 2 *\left(\mathrm{a}^{\prime} / \mathrm{Y} 1\right)^{\wedge} 0.43 * \mathrm{Fr} 1^{\wedge} 0.61+1$

(Richardson and others, 1995, p. 48, eq. 28)

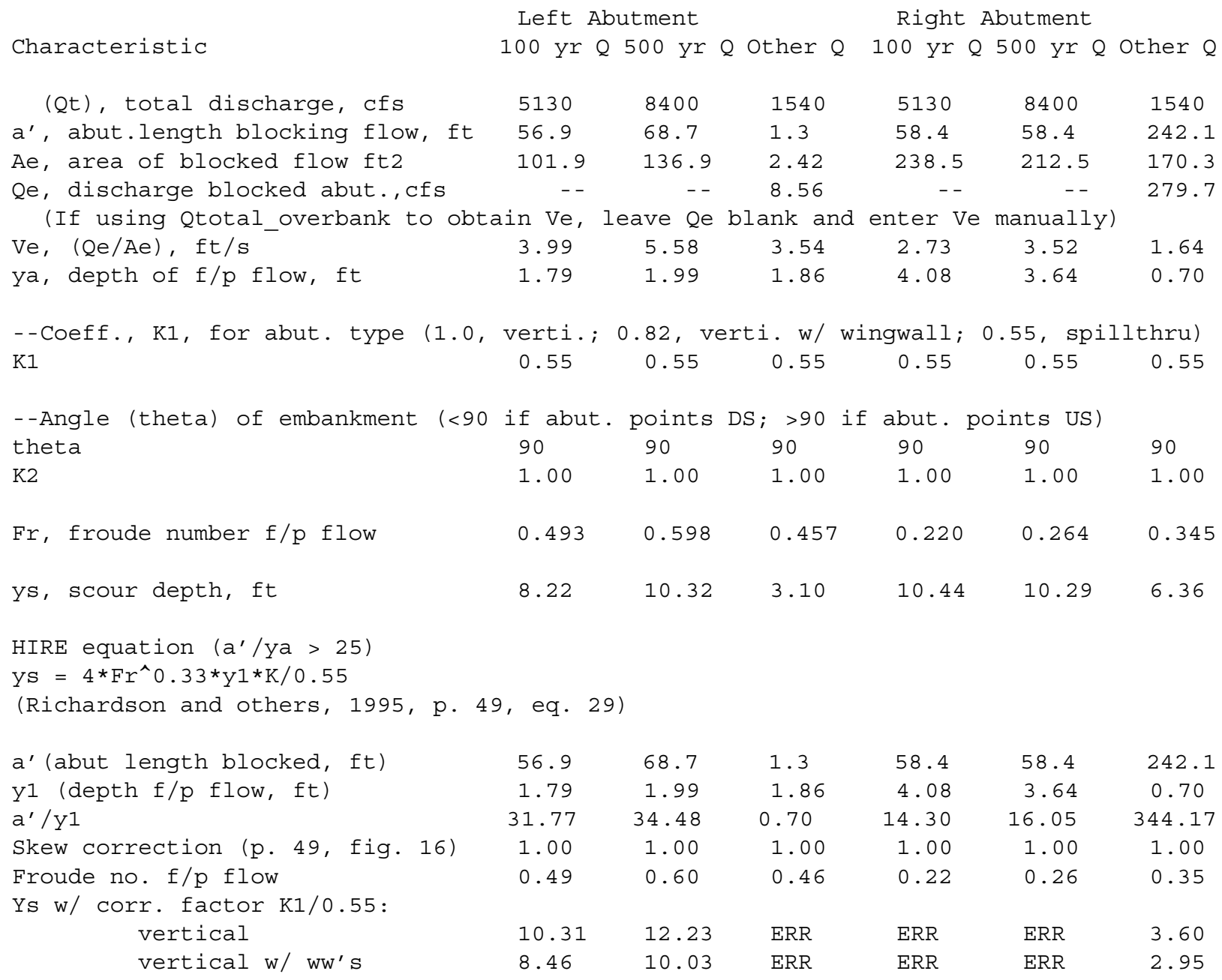




spill-through
Abutment riprap Sizing

